\title{
Long-term observations of black carbon mass concentrations at Fukue Island, western Japan, during 2009-2015: constraining wet removal rates and emission strengths from East Asia
}

\author{
Yugo Kanaya ${ }^{1,2}$, Xiaole Pan ${ }^{3,4}$, Takuma Miyakawa ${ }^{1,2}$, Yuichi Komazaki ${ }^{1}$, Fumikazu Taketani ${ }^{1,2}$, Itsushi Uno ${ }^{4}$, and \\ Yutaka Kondo ${ }^{5}$ \\ ${ }^{1}$ Department of Environmental Geochemical Cycle Research, Japan Agency for Marine-Earth Science and \\ Technology, Yokohama, Kanagawa 2360001, Japan \\ ${ }^{2}$ Institute of Arctic Climate and Environmental Research, Japan Agency for Marine-Earth Science and \\ Technology, Yokohama, Kanagawa 2360001, Japan \\ ${ }^{3}$ Institute of Atmospheric Physics/Chinese Academy of Sciences, State Key Laboratory of Atmospheric Boundary \\ Layer Physics and Atmospheric Chemistry, Beijing, 100029, China \\ ${ }^{4}$ Research Institute for Applied Mechanics, Kyushu University, Kasuga, 816-8580, Japan \\ ${ }^{5}$ National Institute of Polar Research, Tachikawa 1908518, Japan \\ Correspondence to: Yugo Kanaya (yugo@jamstec.go.jp)
}

Received: 11 March 2016 - Published in Atmos. Chem. Phys. Discuss.: 18 March 2016

Revised: 18 June 2016 - Accepted: 6 July 2016 - Published: 30 August 2016

\begin{abstract}
Long-term (2009-2015) observations of atmospheric black carbon (BC) mass concentrations were performed using a continuous soot-monitoring system (COSMOS) at Fukue Island, western Japan, to provide information on wet removal rate constraints and the emission strengths of important source regions in East Asia (China and others). The annual average mass concentration was $0.36 \mu \mathrm{g} \mathrm{m}^{-3}$, with distinct seasonality; high concentrations were recorded during autumn, winter, and spring and were caused by Asian continental outflows, which reached Fukue Island in 6-46 h. The observed data were categorized into two classes, i.e., with and without a wet removal effect, using the accumulated precipitation along a backward trajectory (APT) for the last 3 days as an index. Statistical analysis of the observed $\triangle \mathrm{BC} / \triangle \mathrm{CO}$ ratios was performed to obtain information on the emission ratios (from data with zero APT only) and wet removal rates (including data with nonzero APTs). The estimated emission ratios $\left(5.2-6.9 \mathrm{ng} \mathrm{m}^{-3} \mathrm{ppb}^{-1}\right)$ varied over the six air mass origin areas; the higher ratios for south-central East China $\left(30-35^{\circ} \mathrm{N}\right)$ than for north-central East China $\left(35-40^{\circ} \mathrm{N}\right)$ indicated the relative importance of domestic emissions and/or biomass burning sectors. The significantly higher $\mathrm{BC} / \mathrm{CO}$ emission ratios adopted in the
\end{abstract}

bottom-up Regional Emission inventory in Asia (REAS) version $2\left(8.3-23 \mathrm{ng} \mathrm{m}^{-3} \mathrm{ppb}^{-1}\right)$ over central East China and Korea needed to be reduced at least by factors of 1.3 and 2.8 for central East China and Korea, respectively, but the ratio for Japan was reasonable. The wintertime enhancement of the BC emission from China, predicted by REAS2, was verified for air masses from south-central East China but not for those from north-central East China. Wet removal of BC was clearly identified as a decrease in the $\triangle \mathrm{BC} / \triangle \mathrm{CO}$ ratio against APT. The transport efficiency (TE), defined as the ratio of the $\triangle \mathrm{BC} / \triangle \mathrm{CO}$ ratio with precipitation to that without precipitation, was fitted reasonably well by a stretched exponential decay curve against APT; a single set of fitting parameters was sufficient to represent the results for air masses originating from different areas. An accumulated precipitation of $25.5 \pm 6.1 \mathrm{~mm}$ reduced the TE to $1 / e$. BCcontaining particles traveling to Fukue must have already been converted from hydrophobic to hydrophilic particles, because the behavior of TE against APT was similar to that of $\mathrm{PM}_{2.5}$, the major components of which are hydrophilic. Wet loss of $\mathrm{BC}$ greatly influenced interannual variations in the $\triangle \mathrm{BC} / \triangle \mathrm{CO}$ ratios and $\mathrm{BC}$ mass concentrations. This long- 
term data set will provide a benchmark for testing chemical transport/climate model simulations covering East Asia.

\section{Introduction}

Black carbon (BC) particles suspended in the atmosphere induce positive radiative forcing by absorbing sunlight in the atmosphere and by reducing ice/snow albedo once deposited on such surfaces (IPCC, 2013; Bond et al., 2013; Kondo, 2015; and references therein). The increased mass concentrations of $\mathrm{BC}$ in the atmosphere since pre-industrial times have directly induced warming of the Earth's climate. The atmospheric residence time of $\mathrm{BC}$ particles is only about a week (IPCC, 2013), much shorter than that of $\mathrm{CO}_{2}$, which is a major long-lived greenhouse gas. Because of this, BC is now regarded as an important type of short-lived climate pollutant. Reductions in their emissions could effectively and promptly slow down global temperature increases in the near future (until ca. 2040); such reductions should be coupled to reductions in $\mathrm{CO}_{2}$, which has a longer-term buffering effect on temperature increases (Shindell et al., 2008; Jacobson, 2010; UNEP and WMO, 2011). Besides the relevance to climate change, the World Health Organization warns about the health effects of BC (Janssen et al., 2012).

East Asia, especially China, is a major source of BC (Streets et al., 2003; Bond et al., 2004; Ohara et al., 2007; Zhang et al., 2009; Kurokawa et al., 2013) and may remain the dominant source region of BC particles present over the Pacific and the Arctic (Q. Wang et al., 2011; Zhang et al., 2015; AMAP 2015). However, there is still a large uncertainty regarding the emission strength and geographical distribution. Besides observations within the source areas, more observations from regions downwind of the source areas are needed to elucidate regional features of the atmospheric status and then to constrain the emission and removal rates, to better characterize the effects on the climate and health and establish an effective mitigation strategy.

In observations of $\mathrm{BC}$ mass concentrations in the atmosphere, the reliability of the instrument used is important for robust analyses. We regard single-particle soot photometer (SP2; Droplet Measurement Technologies, Boulder, CO, USA) and ECOC analyzers with optical corrections as reliable, but their use for long-term observations is challenging. Among filter-based techniques, more suitable for long-term observations, continuous soot-monitoring systems (COSMOS or BCM3130; Kanomax, Osaka, Japan) and multi-angle absorption photometers (MAAP; model 5012, Thermo Scientific, Waltham, MA, USA) are satisfactory because the effects of co-existing scattering particles are minimized. For COSMOS, this is achieved by using a pre-heater to remove nonrefractive species (Miyazaki et al., 2008). For MAAP, multi-angle observations with respect to the particleladen filter are made to take account of the scattering effect in the radiative transfer calculation (Petzold et al., 2002). The performances of the two instruments were certified against SP2 and ECOC analyzers as detailed in Sect. 2. For filterbased techniques, using a size cutoff device $\left(\mathrm{PM}_{1}\right.$ or at least $\mathrm{PM}_{2.5}$ ) is important for minimizing interference from coexisting light-absorbing particles such as mineral dust.

Long-term observations using these reliable instruments have started in East Asia in the last decade. Observations using MAAP instruments at Mt. Huang, Anhui Province, China, during 2006-2009 and at Fukue Island, Japan, during 2009-2010 have been reported (Pan et al., 2011; Kanaya et al., 2013a). Kondo and colleagues have successfully used COSMOS instruments to obtain long-term data at Cape Hedo, Happo, and Fukue in Japan, Miyun (a rural site near Beijing), Lulin (Taiwan), and Bangkok (Kondo, 2015; Verma et al., 2011; Liu et al., 2013; Sahu et al., 2011; Y. Wang et al., 2011; Kanaya et al., 2013a). Early data, i.e., during the first 1-3 years, from these ground-based sites have been used to evaluate regional model simulations and emission rates (Matsui et al., 2013; Kondo et al., 2011b) to estimate TE (Verma et al., 2011), and to study wet deposition (Mori et al., 2014). In China, the China Meteorological Administration Atmosphere Watch Network (CAWNET) operates ECOC analyzers at rural sites, using the Interagency Monitoring of Protected Visual Environments (IMPROVE) protocol and optical correction based on thermal/optical reflectance (Zhang et al., 2012). Gosan in Jeju Island, Korea, is a supersite where several instruments (including an ECOC analyzer and a COSMOS) have operated in parallel for more than 5 years (S.-W. Kim, personal communication, 2015). Based on offline ECOC analysis, Chuang et al. (2014) reported long-term (2003-2012) but intermittent observations of elemental carbon at Mountain Lulin Atmospheric Background Station, Taiwan (2862 $\mathrm{m}$ above sea level (a.s.1.)). Although the basic features are generally clarified by analyzing the data for 3 years or less, longer-term (more than 5 years) data are needed to clarify more-detailed features, with better statistical convergence. For example, Verma et al. (2011) used the data for a year from Cape Hedo but could not obtain direct observational evidence of statistically significant wet removal; improved analysis may be possible using a data set covering a longer period.

In this paper, we present data for 6 years (2009-2015) of BC observations at Fukue Island, a remote island located in the westernmost part of Japan, which receives continental outflow with negligible local emissions. Fukue is a unique site, at which a COSMOS and a MAAP have been operated together for a long period, i.e., since 2009 (Kanaya et al., 2013a). The methodology is described in Sect. 2, and the basic features of temporal variations and air mass origins are discussed in Sect. 3.1. In Sect. 3.2, the factors controlling the observed $\mathrm{BC}$ concentrations, such as emission rates and wet removal, are discussed. The analysis was based on the $\triangle \mathrm{BC} / \triangle \mathrm{CO}$ ratios, where delta indicates surplus amounts with respect to the background value, which 
give source-specific information on the emission ratio under dry condition. In this section, the Regional Emission inventory in Asia (REAS) version $2 \mathrm{BC}$ emissions (Kurokawa et al., 2013) are mainly tested in detail; we examine the sourcearea dependence of the $\mathrm{BC} / \mathrm{CO}$ emission ratio over central North/central South China, Korea, and Japan, and the seasonality. The $\triangle \mathrm{BC} / \triangle \mathrm{CO}$ ratio is also useful for analysis of cases with precipitation, as wet removal affects $\mathrm{BC}$ but does not affect CO. As in previous studies (Matsui et al., 2011; Oshima et al., 2012), accumulated precipitation along the trajectory (APT) is used as an index. For the first time, clear evidence of wet removal of $\mathrm{BC}$ is seen as a function of APT from long-term observations at a ground site. The universality of the relationship between APT and BC is discussed. The relationship was parameterized in a way that enabled the model simulation to be easily tested. Finally, the influence of wet removal on the interannual variabilities in $\mathrm{BC}$ mass concentrations is discussed in Sect. 3.3.

\section{Methodology}

The Fukue Island observatory (Fig. $1,32.75^{\circ} \mathrm{N}, 128.68^{\circ} \mathrm{E}$; $75 \mathrm{~m}$ a.s.l.) is located on a peninsula in the northwestern part of Fukue Island $\left(326 \mathrm{~km}^{2}\right)$, in the westernmost part of Japan (Takami et al., 2005; Kanaya et al., 2013a, 2016). The main township is located in the eastern part of the island, and therefore direct observations of continental outflow, free from local emissions, are possible under the west/northwestern wind conditions prevalent during the autumn/winter/spring monsoon period. The distance from the Chinese coastline is about $700 \mathrm{~km}$ from the Shanghai area and about $1000 \mathrm{~km}$ from the Beijing area; the Korean coastline is nearer $(\sim 200 \mathrm{~km})$.

Since April 2009, BC mass concentrations have been monitored using a COSMOS and a MAAP at the Fukue site. The performances of the two instruments have been certified by a series of laboratory and field experiments. The stability of the mass absorption cross section to be used with the COSMOS instrument was ascertained by comparison with $\mathrm{BC}$ mass concentrations determined using an ECOC thermal optical transmittance (TOT) analyzer (Sunset Laboratory, Tigard, OR, USA) in various environments in Asia (Kondo et al., 2009). The results showed that a cross section of $10 \mathrm{~m}^{2} \mathrm{~g}^{-1}$ was appropriate at the used wavelength $(565 \mathrm{~nm})$ when using a PALLFLEX E70-2075W quartz filter. Consistency with the results obtained using a SP2 was also confirmed (Kondo et al., 2011a). The BC concentrations obtained with a MAAP instrument using GF-10 filter roll tape and a manufacturerrecommended mass absorption cross section of $6.6 \mathrm{~m}^{2} \mathrm{~g}^{-1}$ at $639 \mathrm{~nm}$ were consistently higher than those obtained by ECOC analyzers and by COSMOS instruments (or a particle soot absorption photometer equipped with a heater as its precursor) at three locations in China, i.e., at the top of Mt. Tai, Shandong Province, at Mangshan near Beijing, and at Rudong county, Jiangsu Province (Kanaya et al., 2008,

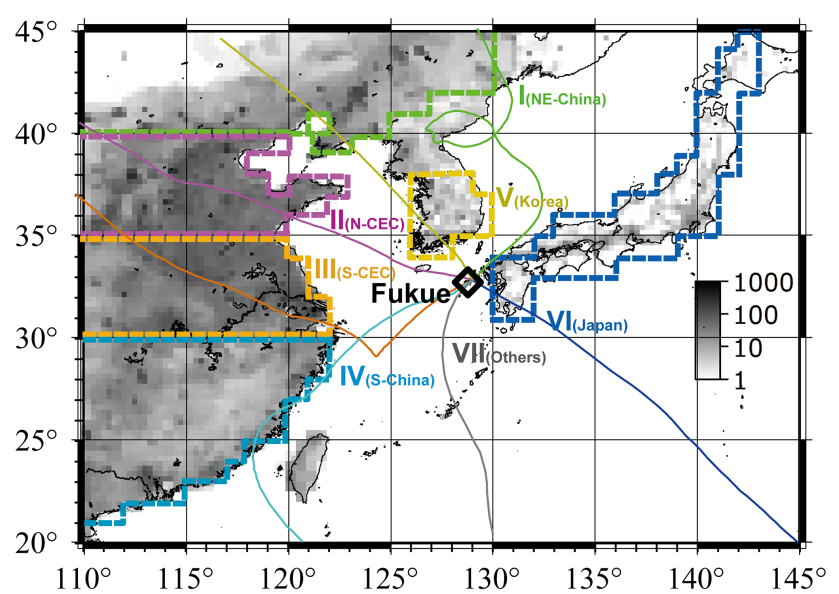

Figure 1. Location of Fukue Island on a black and while contour map, with $\mathrm{BC}$ emission rates $\left[t\right.$ per month $/\left(0.25^{\circ} \times 0.25^{\circ}\right.$ grid $\left.)\right]$ in January 2008 from REAS2 bottom-up inventory (Kurokawa et al., 2013). Borderlines used to classify air mass origin region types are shown by colored broken lines. Example of backward trajectory for each classification is shown by colored solid line.

2013b; Pan et al., 2012, 2013). However, excellent positive correlations with the mass concentrations derived using the COSMOS instrument were found and use of a modified mass absorption cross section, i.e., $\sim 10 \mathrm{~m}^{2} \mathrm{~g}^{-1}$, gave good agreement between the MAAP-derived mass concentrations and the COSMOS results (Kanaya et al., 2013a). Comparisons with results from ECOC analyzers also supported this modification.

The details of the deployment of the instruments at Fukue have been previously reported (Kanaya et al., 2013a). Briefly, a single air intake tube equipped with a cyclone $\left(\mathrm{PM}_{2.5}\right.$ and $\mathrm{PM}_{1}$ before and after November 2011) was used to supply ambient air to the two instruments. The influence of co-existing non-BC particles was small for both instruments because a pre-heater at $400^{\circ} \mathrm{C}\left(300^{\circ} \mathrm{C}\right.$ after December 2013) removed nonrefractive species (e.g., ammonium sulfate, which was dominant at the site) in the case of COSMOS, and reflectance measurements performed at two angles were added to the filter transmittance observations to remove the scattering effect in the case of MAAP. We previously showed a nearly perfect correlation between the data sets from the two instruments at Fukue (Kanaya et al., 2013a) during 2009-2010, although a systematic increase in the mass absorption cross section for MAAP (from 6.6 to $10.3 \mathrm{~m}^{2} \mathrm{~g}^{-1}$ ) was necessary for quantitative agreement, similarly to the aforementioned previous studies in China. Figure 2 shows that this relationship was unchanged for a lengthy period, 2009-2015, indicating long-term robustness of the observations. A recent comparison of the mass concentration obtained with MAAP using the modified mass absorption cross section and that obtained with an SP2 at 


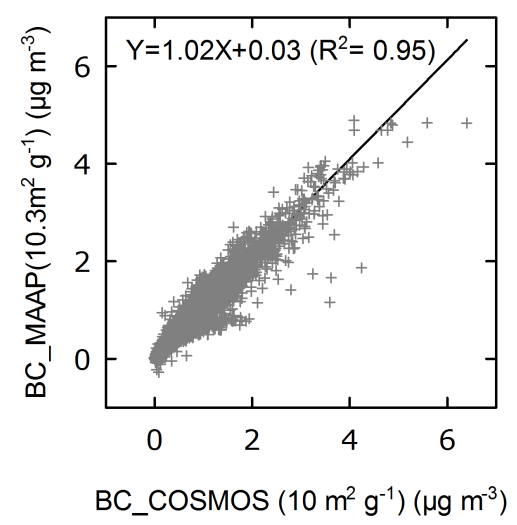

Figure 2. Correlation between hourly BC mass concentrations obtained using COSMOS and MAAP instruments at Fukue Island during 2009-2015.

Fukue Island, Japan, showed close agreement (Miyakawa et al., 2016).

In this study, we used data from the COSMOS instrument, which has a better detection limit $\left(0.047 \mu \mathrm{g} \mathrm{m}^{-3}\right)$. The BC mass concentrations are given as mass concentration per unit volume of air at standard temperature and pressure (STP; $273 \mathrm{~K}$ and $1013 \mathrm{hPa}$ ). The change in the COSMOS pre-heater temperature was recommended by Kondo et al. (2011a) to minimize the effect of charring of organics, but this did not change the relationship with MAAP results. Filter roll tapes of PALLFLEX (E70-2075W) were replaced by HEPA (L$371 \mathrm{M}$ ) in December 2013; a factor of 0.914, accounting for the sensitivity change, was applied to the data after the change, as recommended by Irwin et al. (2015).

The CO mixing ratios at Fukue since 2010 have been observed using a nondispersive infrared absorption photometer (48C, Thermo Scientific, Waltham, MA, USA). A Teflon tube was used to sample ambient air from a height $\sim 5 \mathrm{~m}$ above the ground. The detection limit was estimated to be $40 \mathrm{ppb}$ ( $30 \mathrm{~s}$ averaging time). The zero level was periodically (every $20 \mathrm{~min}$ of each hourly measurement) measured using an external zero air generator equipped with a heated $\left(350^{\circ} \mathrm{C}\right) \mathrm{Pt}$ catalyst. Summertime measurements (June to September) were discarded because until June 2013 the zerolevel observations were made using room air with different water vapor amounts, and this affected the measurements. For the other period, i.e., October to May, a comparison with the results obtained using another $\mathrm{CO}$ instrument at the site showed that the effect was small (S. Yonemura, personal communication, 2015). Span gas (1.09 ppm CO/ $\mathrm{N}_{2}$, TaiyoNissan, Tokyo, Japan) calibrations were performed every few months and the sensitivity fluctuations were estimated to be small $( \pm 4 \%, 1 \sigma)$.

The $\mathrm{PM}_{2.5}$ mass concentrations have been continuously measured since March 2009 using a hybrid (nephelometric and $\beta$-ray absorption) instrument (SHARP5030, Thermo Scientific, Waltham, MA, USA) equipped with a conduc- tive tube inlet and a $\mathrm{PM}_{2.5}$ size cutoff cyclone. The $\mathrm{BC}$ wet removal behavior is discussed with reference to $\mathrm{PM}_{2.5}$ in Sect. "Comparison of TEs for BC and $\mathrm{PM}_{2.5}$ ".

Five-day backward trajectories from an altitude of $500 \mathrm{ma}$ a.s.l. were calculated every $6 \mathrm{~h}$ using the Hybrid Single-Particle Lagrangian Integrated Trajectory (HYSPLIT) model (Draxler and Rolph, 2013), using GDAS1 three-dimensional meteorological field data. We preferred an interval of $6 \mathrm{~h}$ in order to enable each datum to be handled independently. The results for the last 3 days $(72 \mathrm{~h})$ were used in this study. Similarly to Kanaya et al. (2013a), the air mass origins were classified into six categories according to the borderlines (Fig. 1) that the backward trajectories crossed for the first time at altitudes below $2500 \mathrm{~m}$ a.s.1. The types are as follows: (I) Northeast China (NE-C, $>40^{\circ} \mathrm{N}$ ); (II) north-central East China (N-CEC, 35-40 N); (III) southcentral East China (S-CEC, 30-35 N); (IV) South China $\left(\mathrm{SC},<30^{\circ} \mathrm{N}\right)$; (V) Korea (KOR); and (VI) Japan (JPN). Cases that do not fall into the six categories are grouped together as type VII (others). Type V is frequently influenced by other source regions (e.g., N-CEC, type II). For Korean emissions, a subcategory $\mathrm{V}$ ' was defined for cases in which air masses did not travel over any defined regions other than V (see Sect. "Estimates of BC / CO emission ratios: air mass origin dependence, seasonality, and comparisons with past studies and bottom-up emission inventory").

Figure 3 shows all the backward trajectories categorized into each of the seven air mass types; these are the cases with valid $\mathrm{BC}$ and $\mathrm{CO}$ data and are included in the analyses in the following sections. The gray thin lines represent all trajectories during $72 \mathrm{~h}$ where the altitude is lower than $2500 \mathrm{~m}$ a.s.l. Trajectories categorized to areas II and III, to be mainly discussed in the later sections, were also influenced from other areas. Nonetheless, when weighted by BC emission distribution, the effect from other regions was estimated to be $<25 \%$. The colored circles indicate the locations and rates of precipitation. The geographical distribution of the colored circles suggests that most precipitation occurred over the ocean, after the air masses had left the source regions. The APT for the last 3 days calculated with GDAS1 precipitation data was therefore considered to be a useful index and was used both to extract cases not influenced by wet removal processes and to analyze wet removal of $\mathrm{BC}$. When precipitation occurred, trajectories might become less reliable. Nonetheless, we found that the dependence of $\mathrm{CO}$ mixing ratios on air mass origin areas was almost unchanged with the presence of precipitation (Fig. S1 in the Supplement). Therefore, the origin area information was used for further analysis of wet removal. The APT cumulative frequencies for individual air mass types are shown in the lower right panel of Fig. 3. Types II and V were mostly dry; more than $90 \%$ of the cases had APTs less than $10 \mathrm{~mm}$. Type I had a larger fraction of cases with precipitation in the range $10-30 \mathrm{~mm}$, but the fraction with APT $>30 \mathrm{~mm}$ was small $(<2.5 \%)$. Types III, IV, VI, and others had more cases with APT $>30 \mathrm{~mm}$. 

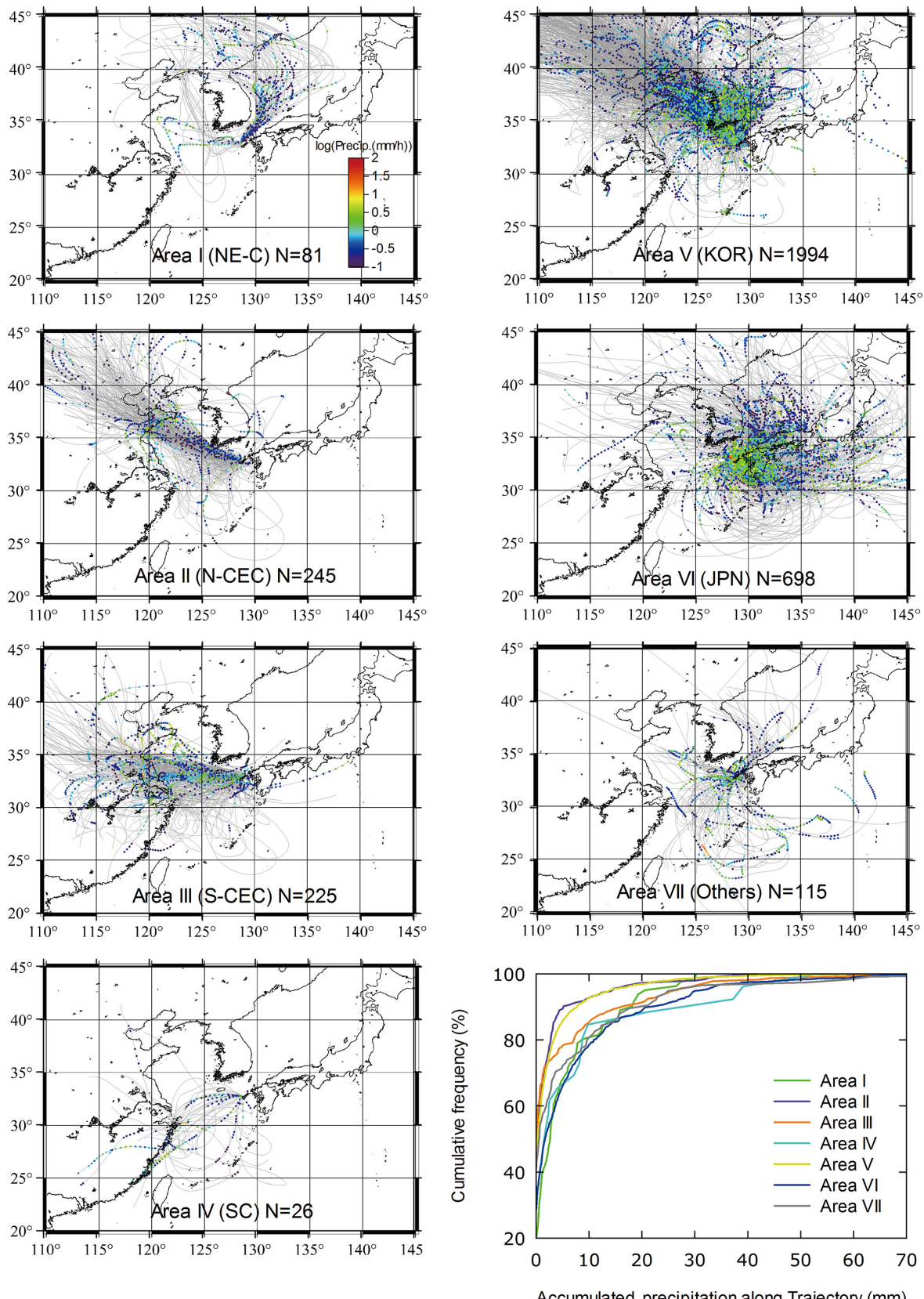

Figure 3. Backward trajectories for cases with valid $\triangle \mathrm{BC} / \triangle \mathrm{CO}$ data were classified into seven air mass types. Gray thin lines indicate within $72 \mathrm{~h}$ and at altitude less than $2500 \mathrm{~m}$ a.s.l. Colored dots indicate precipitation rate $\left(\mathrm{mm} \mathrm{h}^{-1}\right.$, on log scale) and locations. Cumulative frequency (\%) of APT for each category is shown in lower right panel.

\section{Results and discussion}

\subsection{Monthly averages, seasonality, and major source regions}

Table 1 and Fig. 4a show the monthly average BC mass concentrations derived using a COSMOS instrument from April 2009 to March 2015. The annual average was $0.36 \mu \mathrm{g} \mathrm{m}^{-3}$, calculated from $49405 \mathrm{~h}$ of observations. This level was higher than the annual average of $0.29 \mu \mathrm{g} \mathrm{m}^{-3}$, at Cape Hedo $\left(26.87^{\circ} \mathrm{N}, 128.25^{\circ} \mathrm{E} ; 60 \mathrm{~m}\right.$ a.s.l.), Okinawa Island, located in the south of Japan (Verma et al., 2011). The average seasonal variations using all data are shown by a black line in Fig. 5a. There are clear seasonal variations with minima during summer; the monthly concentrations recorded from October to May were $0.38 \mu \mathrm{g} \mathrm{m}^{-3}$ or higher, whereas those from June to September were lower 
Table 1. Monthly average BC mass concentrations derived using COSMOS instrument at Fukue Island (unit: $\mu \mathrm{g}$ STP $\mathrm{m}^{-3}$ ). Number of hourly measurements included in month is in parentheses.

\begin{tabular}{lllllllll}
\hline & 2009 & 2010 & 2011 & 2012 & 2013 & 2014 & 2015 & All \\
\hline January & & $0.63(744)$ & $0.41(716)$ & $0.44(744)$ & $0.38(744)$ & $0.70(744)$ & $0.46(744)$ & 0.53 \\
February & & $0.42(672)$ & $0.79(672)$ & $0.29(696)$ & $0.29(672)$ & $0.47(672)$ & $0.44(672)$ & 0.46 \\
March & & $0.38(739)$ & $0.47(744)$ & $0.44(743)$ & $0.45(724)$ & $0.48(744)$ & $0.39(744)$ & 0.46 \\
April & $0.89(720)$ & $0.36(720)$ & $0.53(720)$ & $0.33(689)$ & $0.33(720)$ & $0.53(720)$ & & 0.51 \\
May & $0.51(744)$ & $0.45(744)$ & $0.41(744)$ & $0.36(744)$ & $0.38(744)$ & $0.56(744)$ & & 0.45 \\
June & $0.44(720)$ & $0.27(692)$ & $0.20(720)$ & $0.17(720)$ & $0.13(720)$ & $0.22(302)$ & & 0.24 \\
July & $0.19(586)$ & $0.31(503)$ & $0.11(744)$ & $0.11(670)$ & $0.10(743)$ & $0.21(253)$ & & 0.15 \\
August & $0.25(744)$ & $0.19(677)$ & $0.14(744)$ & $0.10(744)$ & $0.14(744)$ & $0.14(744)$ & & 0.16 \\
September & $0.29(720)$ & $0.23(529)$ & $0.19(719)$ & $0.15(659)$ & $0.14(720)$ & $0.24(720)$ & & 0.21 \\
October & $0.66(744)$ & $0.40(726)$ & $0.30(744)$ & $0.25(744)$ & $0.16(179)$ & $0.29(744)$ & & 0.38 \\
November & $0.38(720)$ & $0.66(720)$ & $0.29(717)$ & $0.34(720)$ & NA & $0.32(703)$ & & 0.41 \\
December & $0.58(744)$ & $0.56(744)$ & $0.32(744)$ & $0.22(744)$ & $0.47(704)$ & $0.31(744)$ & & 0.42 \\
\hline
\end{tabular}

NA: not available.
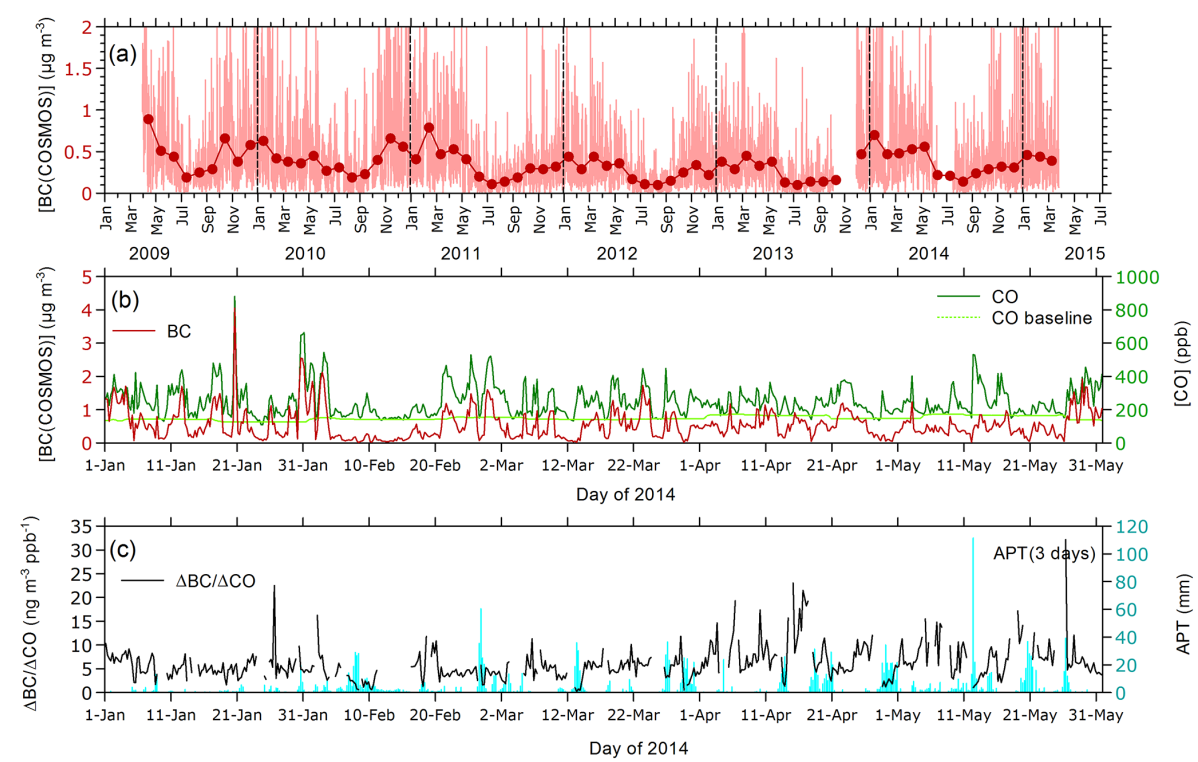

Figure 4. (a) Time series of BC concentrations from COSMOS instrument at Fukue during 2009-2015 (thin line: hourly; dots: monthly averages). (b) and (c) Time series of BC mass concentrations, $\mathrm{CO}$ mixing ratios, $\mathrm{CO}$ baseline mixing ratios, $\triangle \mathrm{BC} / \triangle \mathrm{CO}$ ratios, and $\mathrm{APTs}$ during January-May 2014.

$\left(<0.24 \mu \mathrm{g} \mathrm{m}^{-3}\right)$. Figure 5a also includes average seasonal variations for individual air mass types. The recorded type II and III values were higher throughout the year, clearly suggesting that $\mathrm{N}$ - and S-CEC are the major sources of the BC mass concentrations observed at Fukue Island. The concentrations for types I, IV, and VI were lower than the overall average. The value for air mass type $\mathrm{V}$ was similar to the overall average in winter but tended to be higher in summer. Figure 5b shows the average traveling times for the air masses to reach Fukue after leaving the borderlines. During October to May, the traveling times were around $40 \mathrm{~h}$ for air masses from China (types I to IV); the monthly average traveling times for types II and III ranged from 25 to
$46 \mathrm{~h}$. The major BC-emitting areas are located near the coast (particularly in China); therefore, the traveling time serves as a gauge of the atmospheric residence times of the observed $\mathrm{BC}$ particles. For types V and VI and the overall average, the traveling time was $6-25 \mathrm{~h}$. Figure $5 \mathrm{c}$ shows the relative fractions of each air mass type for individual months. Air mass type $\mathrm{V}$ was dominant except in June to September, when type VI (Japan) and others (basically oceanic) became dominant. During October to May, type VI (Japan) was second in importance, after type $\mathrm{V}$. Air masses arriving directly from CEC (types II and III) accounted for a maximum of $20 \%$, although more cases with indirect influence from Chinese emissions were categorized as type $\mathrm{V}$, because air masses often arrived 

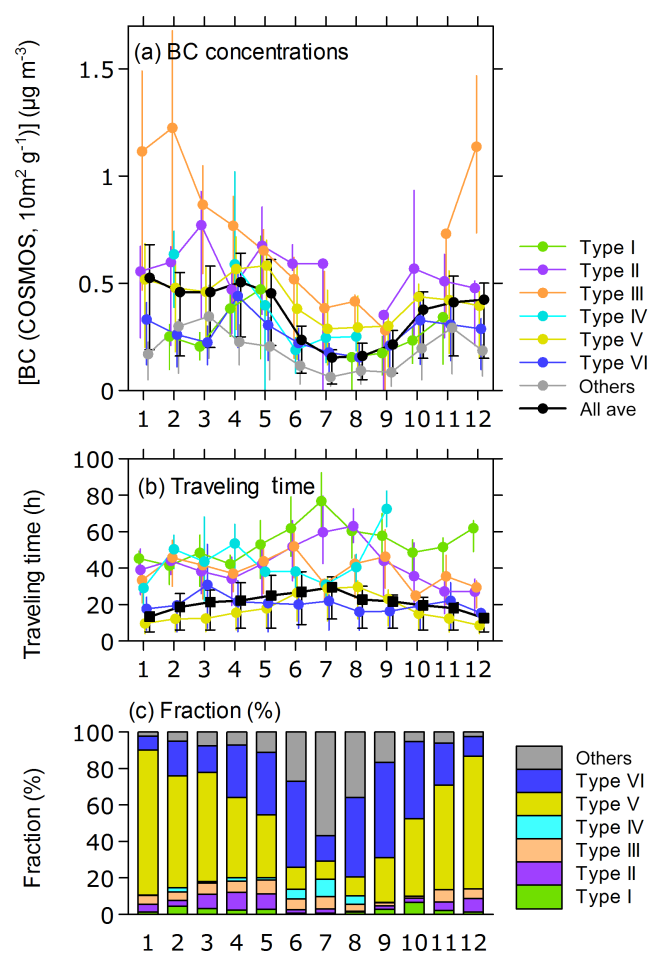

Month

significant loss does not occur. Such losses could occur by wet removal of only $\mathrm{BC}$; therefore in this section we separately discuss the observed $\triangle \mathrm{BC} / \triangle \mathrm{CO}$ ratios for cases with and without precipitation using the APT over the past 3 days as a primary index.

Figure $4 \mathrm{~b}$ and $\mathrm{c}$ show time series of the $\mathrm{BC}$ mass concentrations, $\mathrm{CO}$ mixing ratios, $\triangle \mathrm{BC} / \triangle \mathrm{CO}$ ratios, and APTs at a time resolution of $6 \mathrm{~h}$ during January to May 2014 as an example. Coincident peaks for $\mathrm{BC}$ mass concentrations and $\mathrm{CO}$ mixing ratios were evident, but the $\triangle \mathrm{BC} / \triangle \mathrm{CO}$ ratio showed significant temporal variations and an anti-correlation with APT, indicating that the wet process removed $\mathrm{BC}$ and reduced the $\triangle \mathrm{BC} / \triangle \mathrm{CO}$ ratio. Detailed statistical analyses to retrieve information on the emission ratios and wet removal rates from long-term observations are presented in the following subsections.

\subsubsection{Cases without precipitation}

\section{Evaluation of dry deposition}

Before analysis of the emission ratio, we first prove that dry deposition is not the main removal process that alters the ratio. Figure 6 shows the dependence of the observed $\triangle \mathrm{BC} / \triangle \mathrm{CO}$ ratio (with zero APT) on the traveling time required for the air mass to reach Fukue after leaving the continent, for type II air masses. The ratio does not decrease significantly with traveling time; the time constant of the exponential decay fitting (with a $95 \%$ confidence interval) was $(0.56 \pm 2.12) \times 10^{-3} \mathrm{~h}^{-1}$. This value corresponds to central and upper limit deposition velocities of 0.01 and $0.05 \mathrm{~cm} \mathrm{~s}^{-1}$, respectively, based on the average mixing layer height of $683 \mathrm{~m}$ along the backward trajectory for type II air masses during $72 \mathrm{~h}$ and on the assumption that dry deposition did not affect CO. A dry deposition velocity of $0.1 \mathrm{~cm} \mathrm{~s}^{-1}$, which is typically used for BC in global models (e.g., Emmons et al., 2010), would correspond to the dotted decay line in Fig. 6, indicating that the velocity is overestimated over the ocean. Overall, we conclude that dry deposition did not significantly reduce the $\mathrm{BC}$ mass concentrations for the typical traveling time ranges in this study; therefore neglecting this process will not essentially affect the following discussion on the emission ratio and wet deposition.

variations in the $\mathrm{BC}$ mass concentration. $\triangle \mathrm{CO}$ was culated by subtracting the baseline level (determined as a 14day moving 5th percentile level) from the observed CO mixing ratio. For $\mathrm{BC}$, the baseline concentration was assumed to be zero; therefore $\triangle \mathrm{BC}$ was the same as the original concentration. Only data for October to May with $\Delta \mathrm{CO}$ larger than $20 \mathrm{ppb}$ and positive $\triangle \mathrm{BC}$ values were used for analysis. $\mathrm{BC}$ and $\mathrm{CO}$ are commonly emitted from incomplete fuel combustion, and therefore there is a strong correlation between their atmospheric concentrations. The ratio is not influenced by dilution when sufficient account is taken of their background concentrations. The emission ratio is preserved during travel of the air mass and specific source information can be retrieved from the observed $\triangle \mathrm{BC} / \triangle \mathrm{CO}$ ratio, provided

\section{Estimates of BC / CO emission ratios: air mass origin dependence, seasonality, and comparisons with past studies and bottom-up emission inventory}

The $\triangle \mathrm{BC} / \triangle \mathrm{CO}$ ratios measured without precipitation over the trajectory (i.e., APT $=0 \mathrm{~mm}$ ) were averaged for the classified air mass origin areas (Table 2), assuming insensitivity to traveling time. The features of the estimated emission ratios are discussed in this subsection. First, relative variation of the $\triangle \mathrm{BC} / \triangle \mathrm{CO}$ ratios among the air mass origin areas and seasons is discussed. The observed average ratio for 
Table 2. $\triangle \mathrm{BC} / \triangle \mathrm{CO}$ ratios (average and $1 \sigma$ range) for individual origin area types with and without precipitation. REAS2-derived emission ratios are included for comparison.

\begin{tabular}{|c|c|c|c|c|c|c|c|}
\hline \multirow[t]{2}{*}{ Origin area type } & \multicolumn{3}{|c|}{ Without precipitation } & \multicolumn{2}{|c|}{$\begin{array}{l}\text { With precipitation, } \\
\text { all }(\mathrm{APT} \geq 0.1 \mathrm{~mm})\end{array}$} & \multicolumn{2}{|c|}{$\begin{array}{c}\text { With precipitation, } \\
\text { selected }(\mathrm{APT} \geq 5 \mathrm{~mm})\end{array}$} \\
\hline & $\begin{array}{r}\Delta \mathrm{BC} / \Delta \mathrm{CO} \text { average } \\
\left(\mathrm{ng} \mathrm{m}^{-3} \mathrm{ppb}^{-1}\right)\end{array}$ & $N$ & $\begin{array}{r}\text { REAS2 BC / CO emission ratio } \\
\left(\mathrm{ng} \mathrm{m}^{-3} \mathrm{ppb}^{-1}\right)\end{array}$ & $\begin{array}{r}\Delta \mathrm{BC} / \Delta \mathrm{CO} \text { average } \\
\left(\mathrm{ng} \mathrm{m}^{-3} \mathrm{ppb}^{-1}\right)\end{array}$ & $N$ & $\begin{array}{r}\Delta \mathrm{BC} / \Delta \mathrm{CO} \text { average } \\
\left(\mathrm{ng} \mathrm{m}^{-3} \mathrm{ppb}^{-1}\right)\end{array}$ & $N$ \\
\hline I (NE-China) & $6.0 \pm 2.8$ & 16 & & $5.0 \pm 3.6$ & 65 & $3.3 \pm 2.9$ & 26 \\
\hline II (N-CEC) & $5.3 \pm 2.1$ & 114 & $8.3^{\mathrm{a}}$ & $5.0 \pm 3.8$ & 131 & $3.3 \pm 2.3$ & 27 \\
\hline III (S-CEC) & $6.4 \pm 2.2$ & 115 & $9.9^{\mathrm{b}}$ & $4.5 \pm 2.6$ & 110 & $3.1 \pm 2.0$ & 50 \\
\hline IV (S-China) & $6.9 \pm 1.2$ & 8 & & $5.6 \pm 4.6$ & 18 & $3.5 \pm 2.7$ & 9 \\
\hline V (Korea) & $5.8 \pm 3.0$ & 860 & & $4.7 \pm 3.0$ & 1134 & $3.6 \pm 3.1$ & 290 \\
\hline $\mathrm{V}^{\prime}$ (Korea only) & $6.7 \pm 3.7$ & 199 & 23 & $4.9 \pm 3.2$ & 223 & $3.7 \pm 3.1$ & 65 \\
\hline VI (Japan) & $5.9 \pm 3.4$ & 199 & 6.5 & $4.4 \pm 3.1$ & 499 & $3.3 \pm 2.7$ & 239 \\
\hline
\end{tabular}

${ }^{a}$ Calculated as average over Beijing, Tianjin, Hebei, Shandong, Shanxi. ${ }^{\text {b }}$ Calculated as average over Shanghai, Anhui, Henan, Jiangsu, Hubei.

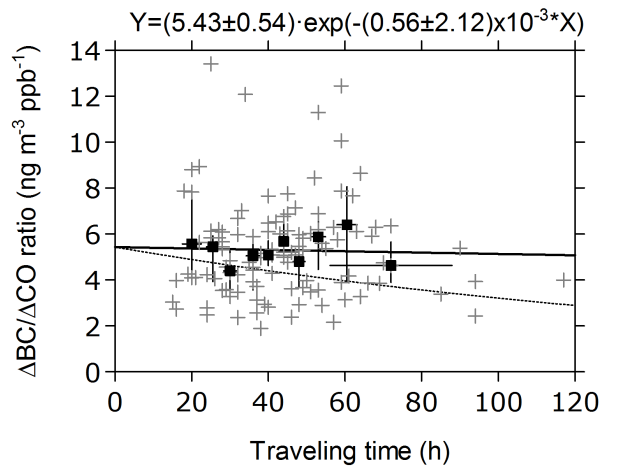

Figure 6. $\triangle \mathrm{BC} / \triangle \mathrm{CO}$ ratio satisfying $\mathrm{APT}=0 \mathrm{~mm}$ plotted against traveling time to determine possible loss of $\mathrm{BC}$ from dry deposition. Raw data (gray plus signs) and 10-bin averages sorted by traveling time (black solid squares) are shown. Exponential decay fitting result is shown by the black solid line. Theoretical decay with a dry deposition velocity of $0.1 \mathrm{~cm} \mathrm{~s}^{-1}$ is shown by a dotted line.

area II (N-CEC, $\left.5.3 \pm 2.1(1 \sigma) \mathrm{ng} \mathrm{m}^{-3} \mathrm{ppb}^{-1}\right)$ was smaller than that for area III (S-CEC, $6.4 \pm 2.2 \mathrm{ng} \mathrm{m}^{-3} \mathrm{ppb}^{-1}$ ). The difference was statistically significant $(p<0.01)$ when Welch's $t$ test was applied to the two data sets. Figure $\mathrm{S} 2$ shows the difference between the frequency distributions of the observed $\triangle \mathrm{BC} / \triangle \mathrm{CO}$ ratios for the two areas. The ratio for type IV (South China) was higher $\left(6.9 \pm 1.2 \mathrm{ng} \mathrm{m}^{-3} \mathrm{ppb}^{-1}\right)$ but the difference between it and the ratio for area II was not statistically significant, mainly because the amount of data was small $(N=8)$. The value for N-CEC is lower than that for S-CEC, in agreement with the results of a past study at Cape Hedo, which gave 7.0 and $7.5 \mathrm{ng} \mathrm{m}^{-3} \mathrm{ppb}^{-1}$ for North China and South China, separated at $33^{\circ} \mathrm{N}$ (Verma et al., 2011). Pan et al. (2011) used MAAP_BC $\left(9.2 \mathrm{~m}^{2} \mathrm{~g}^{-1}\right)$ observations at Mt. Huang $\left(30.16^{\circ} \mathrm{N}, 118.26^{\circ} \mathrm{E} ; 1840 \mathrm{~m}\right.$ a.s.l.; Anhui Province, China) during 2006-2009 to derive $\Delta \mathrm{BC} / \Delta \mathrm{CO}$ ratios and showed that the value for cluster no. 1 from North China (Shanxi, Hebei, Henan, and Shandong provinces) was lower $\left(6.5 \pm 0.4 \mathrm{ng} \mathrm{m}^{-3} \mathrm{ppb}^{-1}\right)$ than that for cluster no. 2, mainly from populated urban areas in the Yangtze delta region $\left(8.8 \pm 0.9 \mathrm{ng} \mathrm{m}^{-3} \mathrm{ppb}^{-1}\right)$ when the air masses were dry. This trend identified from shorter observation periods was confirmed by long-term observations.

The ratio for area type $\mathrm{V}$ (Korea) was $5.8 \pm 3.0 \mathrm{ng} \mathrm{m}^{-3} \mathrm{ppb}^{-1}$ but was higher $\left(6.7 \pm 3.7 \mathrm{ng} \mathrm{m}^{-3} \mathrm{ppb}^{-1}\right)$ for air masses that did not pass over other source regions (type $\mathrm{V}^{\prime}$ ) and became statistically different from the value for area II (see Fig. S2). The ratio for area type VI (Japan) was $5.9 \pm 3.4 \mathrm{ng} \mathrm{m}^{-3} \mathrm{ppb}^{-1}$, and was not statistically different from that for area type II.

We compared these tendencies of the observed $\triangle \mathrm{BC} / \triangle \mathrm{CO}$ ratios with the emission ratios adopted in the bottom-up inventory (Table 2). REAS version 2 (Kurokawa et al., 2013) was chosen as the comparison target, because it covers the pertinent East Asia region and the base year of 2008 is close to our study period. It should be noted that open biomass burning is not included in REAS2, but other major sectors are included. The REAS2-based ratios $\left(1.25 \mu \mathrm{g} \mathrm{m}^{-3} \mathrm{CO}\right.$ at $273 \mathrm{~K}$ and $1013 \mathrm{hPa}$ corresponded to $1 \mathrm{ppb}$ ) were 8.3 and $9.9 \mathrm{ng} \mathrm{m}^{-3} \mathrm{ppb}^{-1}$, respectively, for N-CEC (Beijing, Tianjin, Hebei, Shandong, and Shanxi) and S-CEC (Shanghai, Anhui, Henan, Jiangsu, and Hubei), the main source region subdivisions (see Fig. S3). In terms of relative regional dependences, the observed lower ratio (0.83 times) for N-CEC than for S-CEC was consistent with REAS2 (0.84 times). The three major BC-emitting sectors in REAS2 in China are industry (44\%), transport (11\%), and domestic $(44 \%)$; the $\mathrm{BC} / \mathrm{CO}$ emission ratios were estimated to be $8.7,5.6$, and $15 \mathrm{ng} \mathrm{m}^{-3} \mathrm{ppb}^{-1}$, respectively, in REAS2 for 2008. The higher regional ratio for type III than type II air masses is probably caused by increased $\mathrm{BC}$ (and $\mathrm{CO}$ ) emissions from the domestic sector. Open crop residue burning is another sector with high $\mathrm{BC} / \mathrm{CO}$ emission ratios. Pan et al. (2011) used observations for 3 years of $\triangle \mathrm{BC}$ (MAAP, $9.2 \mathrm{~m}^{2} \mathrm{~g}^{-1}$ ) / $\Delta \mathrm{CO}$ ratios at Mt. Huang in China and found that the ratio was increased by 
the effects of open biomass burning. The influences of these sectors with high $\mathrm{BC} / \mathrm{CO}$ emission ratios could be stronger in S-CEC than in N-CEC.

The REAS2 inventory further predicts that $\mathrm{BC}$ and $\mathrm{CO}$ emissions have significant seasonal variations, with wintertime maxima, mainly because of the increased demand for heating in the domestic sector. In REAS2, the monthly emission rates for December, January, and February (DJF) divided by those for March, April, and May (MAM) were 1.31 and 1.19 for BC and CO, respectively, in 2008 in China (Fig. 7a and b for N-CEC, and Fig. 7d and e for S-CEC). The larger $\mathrm{CO}$ contribution compared with that of $\mathrm{BC}$ from industry flattened the seasonality. As a result, the REAS2 emission inventory predicts that the $\mathrm{BC} / \mathrm{CO}$ emission ratio can be $10 \%$ higher in DJF than in MAM (Fig. 7c and f). Observational detection of such differences was studied for the first time, using the data set for Fukue Island, with source area types II and III. For type II (N-CEC), the average observed $\triangle \mathrm{BC} / \triangle \mathrm{CO}$ ratio in DJF satisfying the condition was $5.4 \pm 2.5$ ( $1 \sigma$ range $) \mathrm{ng} \mathrm{m}^{-3} \mathrm{ppb}^{-1}(N=30)$ and similar to that for MAM, i.e., $5.2 \pm 2.0 \mathrm{ng} \mathrm{m}^{-3} \mathrm{ppb}^{-1}(N=78)$. In contrast, for type III (S-CEC), the average $\Delta \mathrm{BC} / \Delta \mathrm{CO}$ ratio for DJF $\left(7.0 \pm 2.2 \mathrm{ng} \mathrm{m}^{-3} \mathrm{ppb}^{-1}, N=50\right)$ was significantly higher than that for MAM $\left(5.5 \pm 1.6 \mathrm{ng} \mathrm{m}^{-3} \mathrm{ppb}^{-1}\right.$, $N=47$ ). The statistical convergence shows that the difference is statistically significant, based on Welch's $t$ test $(p<0.01)$. The collection of large amounts of data for several years was needed to enable such detailed evaluation of seasonality in the emission inventory. Domestic heating is the driver of seasonality; therefore it was unexpected that only $\mathrm{S}$-CEC, which is generally warmer than N-CEC, showed a significant seasonal difference. This implies that more BCemitting fuels are used for heating in S-CEC than in N-CEC. Prevalence of central heating in N-CEC than S-CEC (China Statistical Yearbook, 2014) might be a cause.

As noticed, the absolute values of the $\mathrm{BC} / \mathrm{CO}$ emission ratios for CEC in REAS2 $\left(8.3\right.$ and $9.9 \mathrm{ng} \mathrm{m}^{-3} \mathrm{ppb}^{-1}$ for N-CEC and S-CEC) are higher than those observed here (5.3 and $6.4 \mathrm{ng} \mathrm{m}^{-3} \mathrm{ppb}^{-1}$ for types II and III) by $\sim 60 \%$. Another emission inventory developed in China, Multi-resolution Emission Inventory for China (MEIC) version 1.0, also had high values: 9.5 and $9.9 \mathrm{ng} \mathrm{m}^{-3} \mathrm{ppb}^{-1}$ for N-CEC and S-CEC, respectively (Li et al., 2015). For Korea, the difference is much larger; the REAS2 value (23.2 $\mathrm{ng} \mathrm{m}^{-3} \mathrm{ppb}^{-1}$, Fig. S3) is $\sim 3.5$ times higher than the observed $\triangle \mathrm{BC} / \Delta \mathrm{CO}$ ratio $\left(6.7 \pm 3.7 \mathrm{ng} \mathrm{m}^{-3} \mathrm{ppb}^{-1}\right.$ for type $\mathrm{V}^{\prime}$ ). Korean emission inventory Clean Air Policy Support System (CAPSS; Lee et al., 2011) had an even higher value, $39.2 \mathrm{ng} \mathrm{m}^{-3} \mathrm{ppb}^{-1}$. Such differences over the continent might be partly influenced by biases in the observations. For example, cloud processes may perhaps reduce the ratio via the shift in size of the ambient BC particles to $>1 \mu \mathrm{m}$, even without precipitation. Indeed, when we more critically choose the conditions (cases with $\mathrm{BC}$ concentrations in the highest $25 \%$ range, with maximum relative humidity (RH)
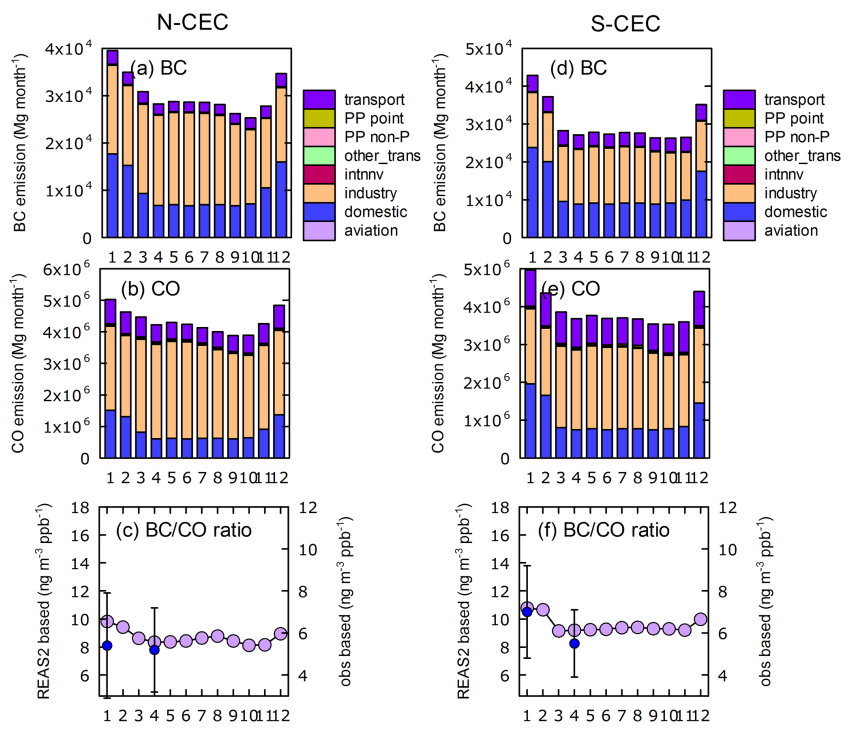

Figure 7. Monthly BC emissions from individual sectors for $\mathrm{BC}$ and $\mathrm{CO}$ and their ratios (purple) for (a-c) N-CEC (Beijing, Tianjin, Hebei, Shandong, and Shanxi) and (d-f) S-CEC (Shanghai, Anhui, Henan, Jiangsu, and Hubei) from REAS2 (Kurokawa et al., 2013). $\mathrm{PP}$ point and PP non-P are power plants identified as point sources and power plants included as non-point sources. In (c) and (f), observed $\triangle \mathrm{BC} / \triangle \mathrm{CO}$ ratios for DJF and MAM at Fukue for those air masses are plotted with blue dots with $1 \sigma$ ranges.

along the trajectory over the previous 3 days in the lowest $25 \%$ range, and with the traveling times in the shortest $25 \%$ range), the observed average $\Delta \mathrm{BC} / \triangle \mathrm{CO}$ ratios increased to 6.0 and $7.6 \mathrm{ng} \mathrm{m}^{-3} \mathrm{ppb}^{-1}$ from 5.3 and $6.4 \mathrm{ng} \mathrm{m}^{-3} \mathrm{ppb}^{-1}$ for types II and III, respectively. Similarly, for the type V' air masses, the observed average $\triangle \mathrm{BC} / \triangle \mathrm{CO}$ ratio increased from 6.7 to $8.4 \mathrm{ng} \mathrm{m}^{-3} \mathrm{ppb}^{-1}$. However, the increase was only $13-25 \%$ and thus would not explain the whole gap. Our value for type II air masses was still lower than the value at Miyun $\left(40.48^{\circ} \mathrm{N}, 116.77^{\circ} \mathrm{E} ; 152 \mathrm{~m}\right.$ a.s.l.) near Beijing during April to October 2010, i.e., $8.4 \pm 0.4 \mathrm{ng} \mathrm{m}^{-3} \mathrm{ppb}^{-1}$ for air masses without wet removal. The difference may arise from differences between the study periods and lengths. Our recent observations of the $\triangle \mathrm{BC} / \triangle \mathrm{CO}$ in the Yangtze River Delta region was $5.9 \mathrm{ng} \mathrm{m}^{-3} \mathrm{ppb}^{-1}$ when urban pollution was dominant (Pan et al., 2012). This value was even lower than our observed ratio for type III air masses. From intensive observations in Jeju Island in spring 2005, Sahu et al. (2009) reported the $\triangle \mathrm{BC} / \triangle \mathrm{CO}$ ratio from Korean Peninsula was $8.5 \mathrm{ng} \mathrm{m}^{-3} \mathrm{ppb}^{-1}$. Park et al. (2005) reported 4.2-6.2 $\mathrm{ng} \mathrm{m}^{-3} \mathrm{ppb}^{-1}$ measured in Gwangju city, Korea, in spring 2001. The two observations support our values for Korea rather than those from emission inventories. Therefore we conclude here modestly that a downward revision in the $\mathrm{BC} / \mathrm{CO}$ emission ratios at least by factors of 2.8 and 1.3 over Korea and CEC, respectively, is necessary for the REAS2 emission inventory. For China, when 
allowing $44 \%$ emission of $\mathrm{BC}$ from the domestic sector as assumed in REAS2, the $\mathrm{BC} / \mathrm{CO}$ emission ratio from that sector $\left(15 \mathrm{ng} \mathrm{m}^{-3} \mathrm{ppb}^{-1}\right)$ in REAS2 is too high to be reconciled. This conclusion is consistent with the results reported by Y. Wang et al. (2011). REAS2 gave a large uncertainty $( \pm 297 \%)$ for the BC emission from the domestic sector in China (Kurokawa et al., 2013). For Korea, the large discrepancy seems to originate from too high $\mathrm{BC} / \mathrm{CO}$ emission ratios assumed for industry and transportation sectors in emission inventory studies (42 and $27 \mathrm{ng} \mathrm{m}^{-3} \mathrm{ppb}^{-1}$ for REAS2 and 357 and $29.5 \mathrm{ng} \mathrm{m}^{-3} \mathrm{ppb}^{-1}$ for CAPSS). In contrast, the observed ratio for Japan $\left(5.9 \mathrm{ng} \mathrm{m}^{-3} \mathrm{ppb}^{-1}\right.$, or $6.7 \mathrm{ng} \mathrm{m}^{-3} \mathrm{ppb}^{-1}$ with the critical choice of the conditions as mentioned above) only differed slightly $(\sim 10 \%)$ from the REAS2 value $\left(6.5 \mathrm{ng} \mathrm{m}^{-3} \mathrm{ppb}^{-1}\right)$, suggesting that the bottom-up inventory is accurate. These values for Japan are also in close agreement with in situ observations in Tokyo during 2003-2005 (5.7 $\left.\mathrm{ng} \mathrm{m}^{-3} \mathrm{ppb}^{-1}\right)$, using an ECOC TOT analyzer with an NIOSH temperature protocol (Kondo et al., 2006).

The $\mathrm{BC}$ emissions from China can be estimated by multiplying the observed $\triangle \mathrm{BC} / \triangle \mathrm{CO}$ ratio by reliable estimates of the $\mathrm{CO}$ emission rate. Recent studies based on top-down estimates using satellite observations (Yumimoto et al., 2014) and field observations (Tohjima et al., 2014) commonly estimated $\mathrm{CO}$ emissions from China in 20092010 to be $\sim 160 \mathrm{Tg}$ year $^{-1}$, whereas the REAS2 bottomup inventory (excluding open biomass burning) suggested $202 \mathrm{Tg}$ year $^{-1}$ with an uncertainty of $\pm 86 \%$ (Kurokawa et al., 2013). Multiplying $\sim 7 \mathrm{ng} \mathrm{m}^{-3} \mathrm{ppb}^{-1}$ (or $0.0056 \mathrm{~g} \mathrm{~g}^{-1}$ ), as average for types II and III air masses, by the range of the $\mathrm{CO}$ emission rate (160-202 $\mathrm{Tg}_{\text {year }}{ }^{-1}$ ) gives an estimated $\mathrm{BC}$ emission from China of $0.90-1.1 \mathrm{Tg}^{-}$year $^{-1}$. In comparison, the bottom-up estimate from REAS2 was $1.59 \mathrm{Tg} \mathrm{year}^{-1}$ for 2008 with an uncertainty of $\pm 176 \%$ (Kurokawa et al., 2013). Zhang et al. (2009) gave an estimation of the BC emission of $1.61 \mathrm{Tg}$ year $^{-1}$. A recent top-down estimate suggested a value of $1.71 \mathrm{Tg}_{\mathrm{year}}{ }^{-1}$ with an uncertainty of $\sim 40 \%$, using model-derived $\mathrm{BC}$ mass concentrations at Cape Hedo corrected for an average model/observed ratio (Kondo, 2015). An even higher BC emission rate over China $\left(2.54 \mathrm{Tg} \mathrm{year}^{-1}\right)$ was recently estimated using ensemble data assimilation (Wang et al., 2016). There are several possible explanations for the lower value in this study; several important BC emission areas located inland of the continent, such as Shanxi, Hubei, and the Sichuan basin, were not well sampled in this study, although the footprint is relatively large, based on long-term observations (Fig. 3). The dry deposition loss of $\mathrm{BC}$ on the continental ground surface was not taken into account. Additionally, seasonal BC emissions from postharvest open crop residue burning, starting in May (Kanaya et al., 2013b; Yamaji et al., 2010), which may have an impact of the order of $0.1 \mathrm{Tg}_{\mathrm{gear}}{ }^{-1}$, were probably not captured because the dominant wind direction during the season did not favor air transport from China to Fukue. Kondo (2015) sug- gested $\mathrm{CO}$ emissions from China had been underestimated by a factor of $\sim 2$. These issues need to be studied simultaneously to further constrain $\mathrm{BC}$ emission rates obtained from the present approach using observed $\triangle \mathrm{BC} / \triangle \mathrm{CO}$ ratios.

The $\mathrm{CO}$ emission rate for Korea in 2008 was estimated to be $0.69 \mathrm{Tg}$ year $^{-1}$ by REAS2 with an uncertainty of $< \pm 131 \%$. Multiplying the observed $\triangle \mathrm{BC} / \triangle \mathrm{CO}$ ratio (8.4 $\mathrm{ng} \mathrm{m}^{-3} \mathrm{ppb}^{-1}$ when conditions were critically selected) by the $\mathrm{CO}$ emission gave an estimated $\mathrm{BC}$ emission from Korea of $0.0046 \mathrm{Tg}_{\text {year }}{ }^{-1}$, which is significantly lower than the REAS2 value of $0.013 \mathrm{Tg}$ year $^{-1}$ (with an uncertainty of $< \pm 257 \%$ ). For Japan, based on a CO emission rate of $5.0 \mathrm{Tg}$ year $^{-1}$ with an uncertainty of $< \pm 131 \%$ by REAS2, the $\mathrm{BC}$ emission rate is estimated to be $0.027 \mathrm{Tg}_{\text {year }}{ }^{-1}$ with similar uncertainty, assuming the observed $\mathrm{BC} / \mathrm{CO}$ emission ratio of $6.7 \mathrm{ng} \mathrm{m}^{-3} \mathrm{ppb}^{-1}$ (with critical condition selection). The value is in good agreement with the REAS2 estimated value of $0.026 \mathrm{Tg} \mathrm{year}^{-1}$, while the uncertainty range was narrowed (as REAS2 was associated by an uncertainty of $< \pm 257 \%$ ).

\subsubsection{Cases with precipitation}

\section{Wet removal rates for $\mathrm{BC}$}

We now extend the analysis to cases where precipitation was present on the trajectories (i.e., APT was nonzero). The overall averages of the observed $\triangle \mathrm{BC} / \triangle \mathrm{CO}$ ratios with precipitation (4.5-5.6 $\mathrm{ng} \mathrm{m}^{-3} \mathrm{ppb}^{-1}$, Table 2) were lower than those without precipitation (5.3-6.9 $\mathrm{ng} \mathrm{m}^{-3} \mathrm{ppb}^{-1}$ ) for all air mass origin types. We can assume that $\mathrm{CO}$ was not influenced; therefore this suggests that $\mathrm{BC}$ was lost by wet processes. When the APT was $5 \mathrm{~mm}$ or more, the ratios were lower, in the range of 3.1-4.8 $\mathrm{ng} \mathrm{m}^{-3} \mathrm{ppb}^{-1}$ (Table 2), and the difference between the wet and dry cases became statistically significant, based on Welch's $t$ test, in all cases $(p<0.01)$.

Figure $8 \mathrm{a}$ shows the dependence of the observed $\triangle \mathrm{BC} / \triangle \mathrm{CO}$ ratio on APT. Cases with all air mass types are included $(N=3384)$. The median ratios for 10 bins sorted by APT (for APT $>0 \mathrm{~mm}$ ), shown by open black circles, clearly show a smooth decrease in the $\triangle \mathrm{BC} / \triangle \mathrm{CO}$ ratio with increases in APT. The TE of BC for a given time $i$ is defined as the $\triangle B C / \triangle C O$ ratio normalized by that without precipitation $\left[(\triangle \mathrm{BC} / \Delta \mathrm{CO})_{\mathrm{APT}}=0\right]$, as described by Matsui et al. (2011) and Oshima et al. (2012):

$\left(\mathrm{TE}_{\mathrm{BC}}\right)_{i}=(\Delta \mathrm{BC} / \Delta \mathrm{CO})_{i} /(\Delta \mathrm{BC} / \Delta \mathrm{CO})_{\mathrm{APT}}=0$.

The $(\Delta \mathrm{BC} / \Delta \mathrm{CO})_{\mathrm{APT}}=0$ values were taken as the median values for all cases or for each air mass type. It should be noted that TE was determined by observations in this study, whereas in some previous studies the TE was determined from modeled BC quantities (e.g., Verma et al., 2011; Oshima et al., 2012). Figure $8 \mathrm{~b}$ shows the median values of TE for 10 bins sorted by nonzero APTs, together with one more point at $\mathrm{APT}=0 \mathrm{~mm}(\mathrm{TE}=1$ by definition) for all 

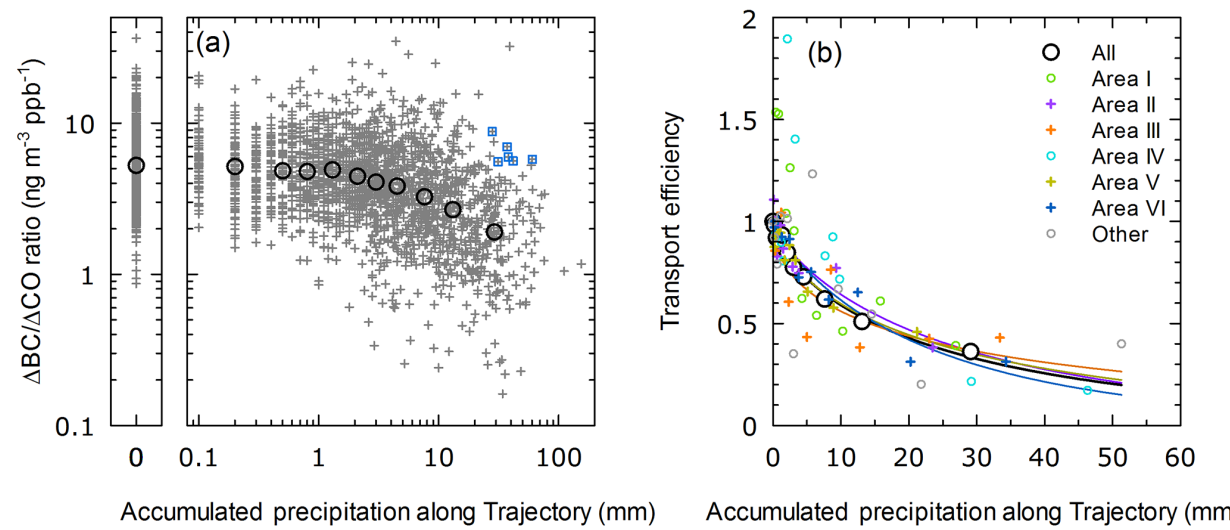

Figure 8. (a) Observed $\triangle \mathrm{BC} / \triangle \mathrm{CO}$ ratios as function of APT. Raw data (gray plus signs) and 10 bins sorted by APT (black open circles) are shown. (b) TE as function of APT for overall cases (black open circles) and for individual air mass origin types (color circles and plus signs). Plus signs indicate air mass types for which large amounts of data are included (see Table 3). Only 10 bins sorted by APT are shown.

Table 3. Results for fitting TE as function of APT for overall data and classified air mass types.

\begin{tabular}{|c|c|c|c|c|c|c|c|}
\hline \multirow[t]{2}{*}{ Origin area type } & \multirow[t]{2}{*}{$\begin{array}{r}N \text { (without } \\
\text { precipitation) }\end{array}$} & \multirow{2}{*}{$\begin{array}{r}N \text { (with precipitation), } \\
\text { binned to } 10 \text { classes } \\
\text { for fitting (Fig. 8) }\end{array}$} & \multicolumn{2}{|c|}{$\begin{array}{c}\text { Fitting parameters } \\
\mathrm{TE}=\exp \left(-A_{1} \times \mathrm{APT}^{A_{2}}\right)\end{array}$} & \multirow[t]{2}{*}{$\begin{array}{r}R^{2} \text { of fitting } \\
(11 \text { points })\end{array}$} & \multirow[t]{2}{*}{$\begin{array}{l}\mathrm{APT}(\mathrm{mm}) \\
(\mathrm{TE}=0.5)\end{array}$} & \multirow[t]{2}{*}{$\begin{array}{l}\mathrm{APT}(\mathrm{mm}) \\
(\mathrm{TE}=1 / e)\end{array}$} \\
\hline & & & $A_{1}$ & $A_{2}$ & & & \\
\hline $\begin{array}{l}\text { All types } \\
\text { (including "others") }\end{array}$ & 1359 & 2025 & $0.109 \pm 0.010$ & $0.684 \pm 0.039$ & 0.99 & $15.0 \pm 3.2$ & $25.5 \pm 6.1$ \\
\hline II (N-CEC) & 114 & 131 & $0.075 \pm 0.029$ & $0.771 \pm 0.156$ & 0.84 & 17.9 & 28.8 \\
\hline III (S-CEC) & 115 & 110 & $0.181 \pm 0.076$ & $0.507 \pm 0.162$ & 0.72 & 14.1 & 29.1 \\
\hline V (Korea) & 860 & 1134 & $0.115 \pm 0.022$ & $0.652 \pm 0.085$ & 0.92 & 15.7 & 27.6 \\
\hline VI (Japan) & 199 & 499 & $0.072 \pm 0.021$ & $0.830 \pm 0.109$ & 0.94 & 15.3 & 23.8 \\
\hline
\end{tabular}

data, indicated by black circles. Figure $8 \mathrm{~b}$ also includes the results for individual air mass types, shown by colored circles and plus signs. Again, smooth decreases with APT are clearly seen in most cases. For area type III, a higher value of $(\triangle \mathrm{BC} / \triangle \mathrm{CO})_{\mathrm{APT}}=0$ was applied for DJF than for other months, as described in the previous section. For five cases (for all data and for area types II, III, V, and VI, shown by plus signs in Fig. 8b), in which large amounts of data were included ( $N \geq 100$ for cases with precipitation, see Table 3 ), the decreasing trend for TE was fitted by the following stretched exponential decay equation with two fitting parameters $\left(A_{1}\right.$ and $\left.A_{2}\right)$ :

$\mathrm{TE}_{\mathrm{BC}}=\exp \left(-A_{1} \times \mathrm{APT}^{A_{2}}\right)$.

The fitting results are shown by black and colored lines in Fig. 8b. The results show that there are high similarities among the cases with different air mass origin area types. This analysis suggests the possibility that wet removal of BC can be parameterized by Eq. (2), with similar fitting parameters for a wide range of cases, at least for cases where ground-based BC concentrations over East Asia are studied. All the fitting parameters and coefficients of determination $\left(R^{2}\right)$ are listed in Table 3 . The $R^{2}$ values were high, in the range of $0.72-0.99$, suggesting that the chosen equa- tion is appropriate. For example, $R^{2}$ decreased to 0.90 when a simple exponential decay equation (i.e., $A_{2}$ was fixed at 1) was used. It should be noted that the fitting equation used is normally used to describe below-cloud scavenging, whereas wet removal of BC is generally believed to be dominated by in-cloud rather than below-cloud processes, because the BC-containing particles are small. This may be why the fitted parameter $A_{1}, 0.109$ for the case using all data, was 2 orders of magnitude larger than that used for below-cloud scavenging [e.g., $1.06 \times 10^{-3}$ (Feng, 2007)] for the particle size range $0.04-2.5 \mu \mathrm{m}$. In contrast, the value of $A_{2}, 0.68$ for the case using all data, was similar to that of 0.61 for below-cloud scavenging (Feng, 2007). The similarity implies that saturation of the removal effect is similar for below- and in-cloud losses. The $A_{2}$ value is important for calculating the TE of BC for longer-range transport, e.g., toward the Arctic. Although decreases in TE with APT have been studied in the past, a different fitting equation was used $[\mathrm{TE}=A-B \log (\mathrm{APT})]$ (Oshima et al., 2012). Use of this equation for fitting our data set resulted in poorer $R^{2}$ values. Based on the larger amount of data and the improved representation of the wet loss process, we propose that the stretched exponential decay equation should be used to ob- 
tain a simple description of the loss process in the model and also for evaluating more sophisticated model simulations.

The fitting results for cases using all data show that the TE reaches 0.5 at an APT of $15.0 \pm 3.2 \mathrm{~mm}$ and $1 / e$ at an APT of $25.5 \pm 6.1 \mathrm{~mm}$ (Table 3). For the individual air mass types (II, III, V, and VI), APT of 14.1-17.9 mm and 23.8-29.1 mm corresponded to TE of 0.5 and $1 / e$ (Table 3). Considering the annual average precipitation of $2335 \mathrm{~mm}$ at Fukue, the 1/ $e$ lifetime of BC due to the wet loss corresponds to $4.0 \pm 1.0$ days. Under drier conditions, however, the $1 / e$ lifetime can become longer: $17.6 \pm 4.2$ days for a site with only $532 \mathrm{~mm}$ of annual precipitation, like Beijing. Even at small APT values (2 mm, chosen by Y. Wang et al. (2011) as the criterion for dry extraction conditions), the TE can be lowered to 0.84. Based on observational data gathered using an aircraft-borne SP2 over the East China Sea during April 2009, Oshima et al. (2012) suggested that the TE reached 0.5 at an APT of $\sim 10 \mathrm{~mm}$ for air masses at altitudes of $2-4 \mathrm{~km}$, in rough agreement with the results of this study. It should be noted that Oshima et al. (2012) suggested a much smaller value of APT for halving TE in the altitude range 4-9 km.

Figure 9 shows the dependence of the 10-bin median $\triangle \mathrm{BC} / \triangle \mathrm{CO}$ ratio on the maximum $\mathrm{RH}$ experienced during travel of the air mass for 3 days before reaching Fukue. The maximum RH, near $100 \%$, would indicate that the air masses were affected by clouds. When all data were used for the analysis (i.e., including data with zero and nonzero APT) median values (black squares) decreased with increases in $\mathrm{RH}$, suggesting possible involvement of cloud processes in $\mathrm{BC}$ particle removal. However, there were a large number of points in a relatively high range $\left(>5 \mathrm{ng} \mathrm{m}^{-3} \mathrm{ppb}^{-1}\right)$ even when the maximum $\mathrm{RH}$ was higher than $95 \%$; therefore this trend was not as clear as the dependence on APT (Fig. 8a). Further subcategorization of the 10th bin (median maximum $\mathrm{RH}=99.9 \%$ ) into cases without precipitation and with precipitation (APT $>10 \mathrm{~mm}$ or more) showed significantly different values (4.7 and $2.3 \mathrm{ng} \mathrm{m}^{-3} \mathrm{ppb}^{-1}$ ). When data with zero APT were only used (red triangles in Fig. 9), the overall decreasing trend became weak; from the difference between the highest and lowest three bins, potential loss of BC by cloud processes without precipitation was estimated to be $16 \%$ at maximum. The estimation is consistent with the 13$25 \%$ increase that occurred with the $(\Delta \mathrm{BC} / \Delta \mathrm{CO})_{\mathrm{APT}=0}$ by the critical choice of $\mathrm{BC}$ concentrations, maximum $\mathrm{RH}$, and traveling time, as discussed in Sect. "Estimates of BC / CO emission ratios: air mass origin dependence, seasonality, and comparisons with past studies and bottom-up emission inventory". These analyses suggest that BC loss is mainly associated with precipitation and is less influenced by clouds. For example, cloud evaporation could result in $\mathrm{BC}$ particle regeneration and $\mathrm{BC}$ mass conservation in the atmosphere, even if the particles had been incorporated into cloud droplets. This could explain why Eq. (2) is appropriate for describing the BC wet removal process. Pan et al. (2011) used the $\triangle \mathrm{BC}$ (MAAP, $9.2 \mathrm{~m}^{2} \mathrm{~g}^{-1}$ ) / $\triangle \mathrm{CO}$ ratio at Mt. Huang to

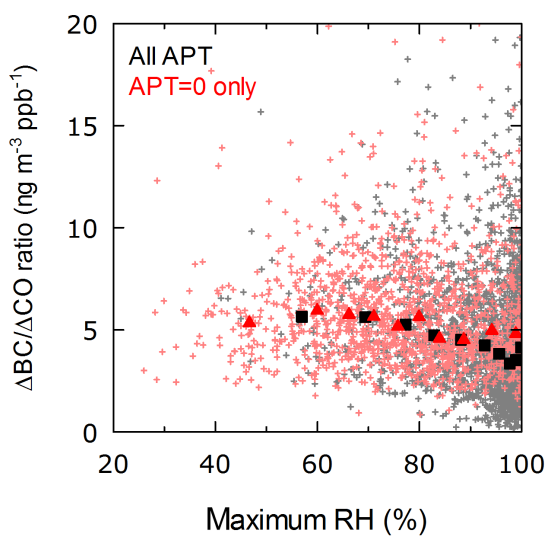

Figure 9. Observed $\Delta \mathrm{BC} / \Delta \mathrm{CO}$ ratios as function of maximum $\mathrm{RH}(\%)$ that air mass experienced in $72 \mathrm{~h}$ before arrival at Fukue Island. All data (irrespective of APT) are shown by gray plus signs, while data with zero APT are shown by red plus signs. Black filled squares and red filled triangles show 10 bins sorted by maximum RH.

show that the ratio was lowered to $0.1 \pm 0.1 \mathrm{ng} \mathrm{m}^{-3} \mathrm{ppb}^{-1}$ after experiencing an RH higher than $70 \%$. This significant decrease with RH is in contrast to the case at Fukue; the difference may arise because at the high altitude on the mountain, cloud droplets frequently co-exist, and the fraction partitioned into the cloud phase could have been missed in the observations. In case of Fukue, when $16 \%$ upshift in the $(\triangle \mathrm{BC} / \Delta \mathrm{CO})_{\mathrm{APT}}=0$ was considered to correct for the potential $\mathrm{BC}$ loss due to in-cloud scavenging without precipitation, a stretched exponential fitting yielded $A_{1}$ and $A_{2}$ values of 0.249 and 0.450 , respectively, and the APT values to reduce TE to $1 / 2$ and $1 / e$ were $9.8 \pm 1.8$ and $22.4 \pm 5.1 \mathrm{~mm}$.

We tried another classification method for cases that experienced cloud processes, using low-cloud bottompressure data from CDAS1, NOAA, and NCEP-NCAR (http://iridl.ldeo.columbia.edu/SOURCES/.NOAA/

.NCEP-NCAR/.CDAS-1/.DAILY/.Diagnostic/.low-cloud/ .bottom/.pressure/). However, we did not find statistically significant differences between the $\triangle \mathrm{BC} / \triangle \mathrm{CO}$ ratios with and without cloud impact. This may be partly because the spatiotemporal resolution of the CDAS1 data was not very high (daily, $2.8^{\circ}$ latitude $\times 1.9^{\circ}$ longitude).

We further investigated six exceptional cases, surrounded by light blue squares in Fig. 8a, in which relatively high $\triangle \mathrm{BC} / \triangle \mathrm{CO}$ ratios $\left(5.5-8.8 \mathrm{ng} \mathrm{m}^{-3} \mathrm{ppb}^{-1}\right)$ were observed, although the APTs were high $(28-60 \mathrm{~mm})$. They were commonly associated with air masses traveling from the south via the East China Sea with a clockwise anticyclonic motion. Most rainfall occurred within $24 \mathrm{~h}$ and the air traveled very near the surface $(950-1000 \mathrm{hPa})$, lower than the bottom of low-cloud height (typically at around $900 \mathrm{hPa}$ ). The good separation in altitude from clouds might explain the weak influence of wet removal. It is also possible that fresh emissions from ships in the East China Sea might have af- 

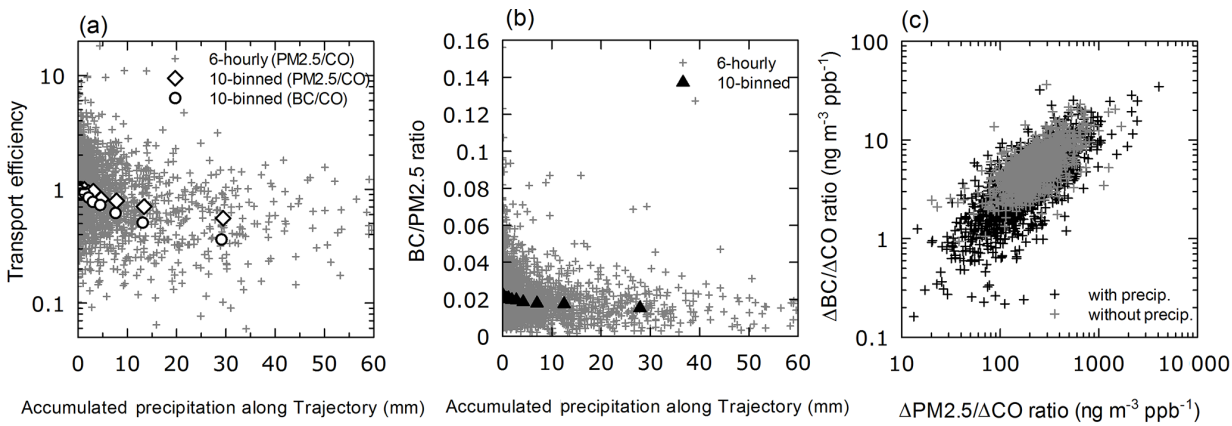

Figure 10. (a) Dependence on APT of transport efficiency of $\mathrm{PM}_{2.5}$ based on $\Delta \mathrm{PM}_{2.5} / \Delta \mathrm{CO}$ ratio (raw: gray plus signs; 10 bin median values: open diamonds) and compared with that of TE for $\mathrm{BC}$ (open circles). (b) Observed BC / $\mathrm{PM}_{2.5}$ ratio (raw: gray plus signs; 10 bin median values: black filled triangles) plotted against APT. (c) $\Delta \mathrm{BC} / \Delta \mathrm{CO}$ ratio plotted against $\Delta \mathrm{PM}_{2.5} / \Delta \mathrm{CO}$ ratio for cases with (black) and without (gray) precipitation.

fected these cases. REAS2 used a $\mathrm{BC} / \mathrm{CO}$ emission ratio of $30 \mathrm{ng} \mathrm{m}^{-3} \mathrm{ppb}^{-1}$ for international navigation (Kurokawa et al., 2013).

Overall, Eq. (2) currently best represents BC removal with precipitation. In the future, independent observations of the $\Delta \mathrm{BC} / \Delta \mathrm{CO}$ ratios at other locations should be used to verify the relationship. The results from regional- or global-scale model simulations using parameterizations to represent wet removal should also be tested against Eq. (2). This would enable removal rates to be tested independently from emission rates in the models.

\section{Comparison of TEs for $\mathrm{BC}$ and $\mathrm{PM}_{2.5}$}

We investigated whether $\mathrm{BC}$ was less efficiently removed by precipitation than other, more soluble, fine particles, based on continuous observations of $\mathrm{PM}_{2.5}$ mass concentrations at Fukue observatory. For consistency, the $\mathrm{PM}_{2.5}$ data for June to September were not used, and only data for $\mathrm{PM}_{2.5}$ larger than $2 \mu \mathrm{g} \mathrm{m}^{-3}$ were used. Generally, emitted BC particles are originally hydrophobic and become hydrophilic with aging because of coagulation with other particles. More than $50 \%$ of the $\mathrm{PM}_{2.5}$ mass concentrations at Fukue Island consisted of water-soluble inorganic species such as ammonium sulfate and ammonium nitrate (Ikeda et al., 2014; Takami et al., 2005). $\mathrm{PM}_{2.5}$ was therefore regarded as a proxy for soluble fine particles. If wet removal of $\mathrm{BC}$ is less efficient than $\mathrm{PM}_{2.5}$ removal, the observed BC-containing particles would still be hydrophobic.

Figure 10a shows that the TE calculated for $\mathrm{PM}_{2.5}$ $\left(\mathrm{TE}_{\mathrm{PM}_{2.5}}\right)$ decreased with APT, as in the case of $\mathrm{TE}_{\mathrm{BC}}$. The median values of $\mathrm{TE}_{\mathrm{PM}_{2.5}}$ for 10 bins were slightly higher than those for $\mathrm{BC}$, suggesting that $\mathrm{PM}_{2.5}$ was removed by a wet process similarly to (or less efficiently than) BC. We concluded that the working hypothesis was not supported that BC-containing particles were less efficiently removed by precipitation than other soluble fine particles. The result was unchanged even when secondary production of $\mathrm{PM}_{2.5}$ was

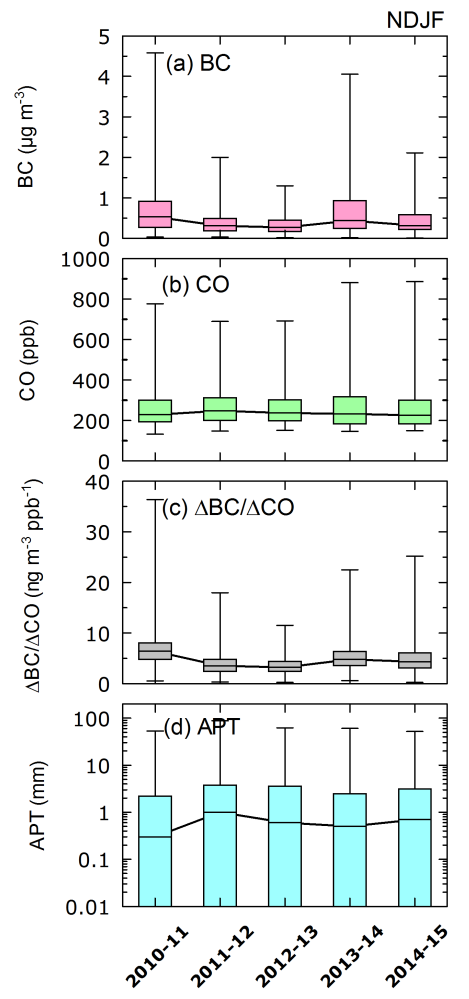

Figure 11. Interannual variations in (a) $\mathrm{BC}$ mass concentrations, (b) $\mathrm{CO}$ mixing ratios, (c) $\Delta \mathrm{BC} / \Delta \mathrm{CO}$ ratios, and (d) APTs, during November-February for 5-year period.

first estimated as a function of traveling time by analyzing data without precipitation and then corrected for all data. Figure $10 \mathrm{~b}$ shows that the $\mathrm{BC}$ fraction of $\mathrm{PM}_{2.5}$ was almost constant $(\sim 2 \%)$ over a wide APT range; again, this contradicts the hypothesis. Figure 10c shows that the $\triangle \mathrm{BC} / \triangle \mathrm{CO}$ ratio decreased with precipitation, similarly to the $\Delta \mathrm{PM}_{2.5} / \Delta \mathrm{CO}$ ratio, indicating that the $\mathrm{BC}$ removal efficiency was similar to that of $\mathrm{PM}_{2.5}$. All these analyses suggest that $\mathrm{BC}$-containing particles arriving at Fukue were already hydrophilic. Obser- 
vations performed using the SP2 instrument showed that the major fraction of single-BC-containing particles was internally mixed with more soluble components (Shiraiwa et al., 2008; Miyakawa et al., 2016), consistent with our conclusions here.

Zhang et al. (2015), using global model simulations and aircraft observations, deduced that BC particles emitted from East Asia in January, November, June, and August became hydrophilic within $4 \mathrm{~h}$, whereas those emitted in April took $38 \mathrm{~h}$. The traveling time from the continent in this study was typically $10-40 \mathrm{~h}$; therefore our results are consistent with their analysis.

\subsection{Interannual variations}

We found that interannual variations in the $\triangle \mathrm{BC} / \triangle \mathrm{CO}$ ratios and $\mathrm{BC}$ mass concentrations were greatly influenced by wet loss of $\mathrm{BC}$ during November to February of the 5 years studied (Fig. 11). The BC mass concentrations were lower in winter in 2011-12 and 2012-13 than in the other years (Fig. 11a and Table 1). The $\mathrm{CO}$ mixing ratios were higher in these 2 years (Fig. 11b), suggesting that the low BC concentration was not explained simply by the reduced influences of source regions. The low $\triangle \mathrm{BC} / \triangle \mathrm{CO}$ ratios in these 2 years (Fig. 11c) clearly corresponded to higher APTs (Fig. 11d). A similar relationship was found for March to May (data not shown). This analysis clearly shows the importance of wet loss in the determination of $\mathrm{BC}$ mass concentration after transport.

\section{Summary}

Fukue Island is located in the East China Sea and receives air masses from China, Korea, and Japan, with typical traveling time from these source areas ranging from 10 to $60 \mathrm{~h}$. Long-term observations of BC mass concentrations at this location during 2009-2015 were discussed in terms of seasonal variations and dominant source areas. High concentrations were recorded during October to May and for air masses from central East China. APT was used as an index for classifying air masses that had experienced precipitation during the last $72 \mathrm{~h}$. For air masses without precipitation (i.e., $\mathrm{APT}=0 \mathrm{~mm}$ ), the observed $\triangle \mathrm{BC} / \triangle \mathrm{CO}$ ratios were statistically analyzed to estimate the emission ratios. The ratio for S-CEC was estimated to be larger than that for N-CEC, and showed wintertime increases, suggesting the importance of domestic influences. This was qualitatively in agreement with the bottom-up emission inventory REAS2. Quantitatively, however, the observed ratios for air masses originating from $\mathrm{CEC}$ and Korea were significantly smaller than the $\mathrm{BC} / \mathrm{CO}$ emission ratios used in the inventory, at least by factors of 1.3 and 2.8, respectively, pointing to the necessity of revising the emission database. The analysis of the observed $\triangle \mathrm{BC} / \triangle \mathrm{CO}$ ratios was then extended to include air masses with precipitation (i.e., APT $>0 \mathrm{~mm}$ ) to study the wet removal of $\mathrm{BC}$. The $\triangle \mathrm{BC} / \triangle \mathrm{CO}$ ratio clearly decreased with APT; therefore the TE, defined as the $\triangle \mathrm{BC} / \triangle \mathrm{CO}$ ratio normalized by the ratio without precipitation, was used for further investigations. The dependence of TE on APT was insensitive to the source region, suggesting that it is universal in nature. We proposed a stretched exponential decay equation with a single set of fitting parameters to describe the wet removal rate. At an APT of $25.5 \pm 6.1 \mathrm{~mm}$, wet removal reduced the TE to $1 / e$. The BC-containing particles arriving at Fukue were already hydrophilic; the wet removal behavior was the same as that for $\mathrm{PM}_{2.5}$. The effects of wet removal were greater in the winters of 2011-12 and 2012-13 than in those of 2010-11, 2013-14, and 2014-15 and dominated the interannual variabilities of the BC mass concentrations. The results of this study show that emission and wet removal must be determined separately to obtain adequate descriptions of $\mathrm{BC}$ behavior in model simulations in order to enable mitigation of the impacts of $\mathrm{BC}$ on the climate and health.

\section{Data availability}

Hourly BC mass concentration data are available from http://ebcrpa.jamstec.go.jp/atmoscomp/obsdata/ (JAMSTEC, 2016). For use of presentations and publications, data users must contact the corresponding author in advance and cite this paper as a reference.

The Supplement related to this article is available online at doi:10.5194/acp-16-10689-2016-supplement.

Acknowledgements. This work was supported by the Environmental Research and Technology Development Fund (S-7, 2-1403, 2-1505) of the Ministry of the Environment, Japan, KAKENHI grant numbers $16 \mathrm{H} 01770$ and 25220101, and by the ArCS (Arctic Challenge for Sustainability) Project of the Ministry of Education, Culture, Sports, Science and Technology of Japan. Dr. Sho Ohata (the University of Tokyo) is acknowledged for his support by preparing the COSMOS instrument. Mr. Minoru Kubo, Dr. Akinori Takami (National Institute for Environmental Studies), Dr. Tamio Takamura, and Dr. Hitoshi Irie (Chiba University) are acknowledged for their support at the Fukue Island Atmospheric Environment Monitoring Station. Dr. Kazuyo Yamaji (Kobe University) is thanked for her discussions of the dry deposition of black carbon. Dr. Seiichiro Yonemura (National Institute for Agro-Environmental Sciences) is acknowledged for evaluating CO data.

Edited by: Q. Zhang

Reviewed by: two anonymous referees 


\section{References}

AMAP: Arctic Monitoring and Assessment Programme, AMAP Assessment 2015: Black carbon and ozone as Arctic climate forcers, Oslo, Norway, vii +, 116 pp., 2015.

Bond, T. C., Streets, D. G., Yarber, K. F., Nelson, S. M., Woo, J.-H., and Klimont, Z.: A technology-based global inventory of black and organic carbon emissions from combustion, J. Geophys. Res., 109, D14203, doi:10.1029/2003JD003697, 2004.

Bond, T. C., Doherty, S. J., Fahey, D. W., Forster, P. M., Berntsen, T., DeAngelo, B. J., Flanner, M. G., Ghan, S., Karcher, B., Koch, D., Kinne, S., Kondo, Y., Quinn, P. K., Sarofim, M. C., Schultz, M. G., Schulz, M., Venkataraman, C., Zhang, H., Zhang, S., Bellouin, N., Guttikunda, S. K., Hopke, P. K., Jacobson, M. Z., Kaiser, J. W., Klimont, Z., Lohmann, U., Schwarz, J. P., Shindell, D., Storelvmo, T., Warren, S. G., and Zender, C. S.: Bounding the role of black carbon in the climate system: A scientific assessment, J. Geophys. Res.-Atmos., 118, 5380-5552, doi:10.1002/Jgrd.50171, 2013.

China Statistical Yearbook 2014: National Bureau of Statistics of China, China Statistics Press, Beijing, 937 pp., ISBN-13: 978$7503772801,2014$.

Chuang, M-T., Lee, C-T., Chou, C. C-K., Lin, N-H., Sheu, G-R., Wang, J-L., Chang, S-C., Wang, S-H., Chi, K. H., Young, CY., Huang, H., Chen, H-W., Weng, G-H., Lai, S-Y., Hsu, S-P., Chang, Y-J., Chang, J-H., and Wu, X-C.: Carbonaceous aerosols in the air masses transported from Indochina to Taiwan: Longterm observation at Mt. Lulin, Atmos. Environ., 89, 507-516, 2014.

Draxler, R. R. and Rolph, G. D.: HYSPLIT (HYbrid Single-Particle Lagrangian Integrated Trajectory) Model access via NOAA ARL READY Website, available at: http://www.arl.noaa.gov/ HYSPLIT.php (last access: 8 August 2016), NOAA Air Resources Laboratory, College Park, MD, 2013.

Emmons, L. K., Walters, S., Hess, P. G., Lamarque, J.-F., Pfister, G. G., Fillmore, D., Granier, C., Guenther, A., Kinnison, D., Laepple, T., Orlando, J., Tie, X., Tyndall, G., Wiedinmyer, C., Baughcum, S. L., and Kloster, S.: Description and evaluation of the Model for Ozone and Related chemical Tracers, version 4 (MOZART-4), Geosci. Model Dev., 3, 43-67, doi:10.5194/gmd3-43-2010, 2010.

Feng, J.: A 3-mode parameterization of below-cloud scavenging of aerosols for use in atmospheric dispersion models, Atmos. Environ., 41, 6808-6822, 2007.

Ikeda, K., Yamaji, K., Kanaya, Y., Taketani, F., Pan, X., Komazaki, Y., Kurokawa, J., and Ohara T.: Sensitivity analysis of source regions of $\mathrm{PM}_{2.5}$ concentration at Fukue Island, J. Air Waste Manage. Assoc., 64, 445-452, 2014.

IPCC: Climate Change 2013: The Physical Science Basis, Cambridge University Press, Cambridge, United Kingdom and New York, NY, USA, 2013.

Irwin, M., Kondo, Y., and Moteki, N.: An empirical correction factor for filter-based photo-absorption black carbon measurements, J. Aerosol Sci., 80, 86-97, 2015.

Jacobson, M. Z.: Short-term effects of controlling fossil-fuel soot, biofuel soot and gases, and methane on climate, Arctic ice, and air pollution health. J. Geophys. Res. 115, D14209, doi:10.1029/2009JD013795, 2010.
JAMSTEC: Observational data of Atmospheric Chemistry, available at: https://ebcrpa.jamstec.go.jp/atmoscomp/obsdata/, last access: 14 August 2016.

Janssen, N. A. H., Gerlofs-Nijland, M. E., Lanki, T., Salonen, R. O., Cassee, F., Hoek, G., Fischer, P., Brunekreef, B., Krzyzanowski, M.: Health effects of black carbon, The WHO European Centre for Environment and Health, Bonn, Germany, World Health Organisation Regional Office for Europe, Copenhagen, Denmark, 86 pp., ISBN-13: 978928900265 3, 2012.

Kanaya, Y., Komazaki, Y., Pochanart, P., Liu, Y., Akimoto, H., Gao, J., Wang, T., and Wang, Z.: Mass concentrations of black carbon measured by four instruments in the middle of Central East China in June 2006, Atmos. Chem. Phys., 8, 7637-7649, doi:10.5194/acp-8-7637-2008, 2008.

Kanaya, Y., Taketani, F., Komazaki, Y., Liu, X., Kondo, Y., Sahu, L. K., Irie, H., and Takashima, H.: Comparison of black carbon mass concentrations observed by Multi-Angle Absorption Photometer (MAAP) and Continuous Soot-Monitoring System (COSMOS) on Fukue Island and in Tokyo, Japan, Aerosol Sci. Technol., 47, 1-10, 2013a.

Kanaya, Y., Akimoto, H., Wang, Z.-F., Pochanart, P., Kawamura, K., Liu, Y., Li, J., Komazaki, Y., Irie, H., Pan, X.-L., Taketani, F., Yamaji, K., Tanimoto, H., Inomata, S., Kato, S., Suthawaree, J., Okuzawa, K., Wang, G., Aggarwal, S. G., Fu, P. Q., Wang, T., Gao, J., Wang, Y., and Zhuang, G.: Overview of the Mount Tai Experiment (MTX2006) in central East China in June 2006: studies of significant regional air pollution, Atmos. Chem. Phys., 13, 8265-8283, doi:10.5194/acp-13-8265-2013, 2013 b.

Kanaya, Y., Tanimoto, H., Yokouchi, Y., Taketani, F., Komazaki, Y., Irie, H., Takashima, H., Pan, X., Nozoe, S., and Inomata, S.: Diagnosis of Photochemical Ozone Production Rates and Limiting Factors in Continental Outflow Air Masses Reaching Fukue Island, Japan: Ozone-Control Implications, Aerosol Air Quality Res., 16, 430-441, 2016.

Kondo, Y.: Effects of Black Carbon on Climate: Advances in Measurement and Modeling, Monogr. Environ. Earth Planets, 3, 185, 2015.

Kondo, Y., Komazaki, Y., Miyazaki, Y., Moteki, N., Takegawa, N., Kodama, D., Deguchi, S., Nogami, M., Fukuda, M., Miyakawa, T., Morino, Y., Koike, M., Sakurai, H., and Ehara, K.: Temporal variations of elemental carbon in Tokyo, J. Geophys. Res., 111, doi:10.1029/2005JD006257, 2006.

Kondo, Y., Sahu, L., Kuwata, M., Miyazaki, Y., Takegawa, N., Moteki, N., Imaru, J., Han, S., Nakayama, T., Hu, M., Kim, Y. J., and Kita, K.: Stabilization of the mass absorption cross section of black carbon for filter-based absorption photometry by the use of a heated inlet, Aerosol Sci. Technol., 43, 741-756, 2009.

Kondo, Y., Sahu, L., Moteki, N., Khan, F., Takegawa, N., Liu, X., Koike, M., and Miyakawa, T.: Consistency and traceability of black carbon measurements made by laser-induced incandescence, thermal-optical transmittance, and filter-based photoabsorption techniques, Aerosol Sci. Technol., 45, 295-312, doi:10.1080/02786826.2010.533215, 2011a.

Kondo, Y., Oshima, N., Kajino, M., Mikami, R., Moteki, N., Takegawa, N., Verma, R. L., Kajii, Y., Kato, S., and Takami, A.: Emissions of black carbon in East Asia estimated from observations at a remote site in the East China Sea, J. Geophys. Res., 116, D16201, doi:10.1029/2011JD015637, 2011 b. 
Kurokawa, J., Ohara, T., Morikawa, T., Hanayama, S., JanssensMaenhout, G., Fukui, T., Kawashima, K., and Akimoto, H.: Emissions of air pollutants and greenhouse gases over Asian regions during 2000-2008: Regional Emission inventory in ASia (REAS) version 2, Atmos. Chem. Phys., 13, 11019-11058, doi:10.5194/acp-13-11019-2013, 2013.

Lee, D. G., Lee, Y.-M., Jang, K.-W., Yoo, C., Kang, K.-H., Lee, J.-H., Jung, S.-W., Park, J.-M., Lee, S.-B., Han, J.-S., Hong, J.H., and Lee, S.-J.: Korean national emissions inventory system and 2007 air pollutant emissions, Asian J. Atmos. Environ., 5, 278-291, 2011.

Li, M., Zhang, Q., Kurokawa, J., Woo, J.-H., He, K. B., Lu, Z., Ohara, T., Song, Y., Streets, D. G., Carmichael, G. R., Cheng, Y. F., Hong, C. P., Huo, H., Jiang, X. J., Kang, S. C., Liu, F., Su, H., and Zheng, B.: MIX: a mosaic Asian anthropogenic emission inventory for the MICS-Asia and the HTAP projects, Atmos. Chem. Phys. Discuss., 15, 34813-34869, doi:10.5194/acpd-1534813-2015, 2015.

Liu, X., Kondo, Y., Ram, K., Matsui, H., Oshima, N., Nakagomi, K., Ikeda, T., Oshima, N., Verma, R. L., Takegawa, N., Koike, M., and Kajino, M.: Seasonal variations of black carbon observed at the remote mountain site Happo in Japan, J. Geophys. Res., 118, 3709-3722, doi:10.1002/jgrd.50317, 2013.

Matsui, H, Kondo, Y., Moteki, N., Takegawa, N., Sahu, L. K., Zhao, Y., Fuelberg, H. E., Sessions, W. R., Diskin, G., Blake, D. R., Wisthaler, A., and Koike, M.: Seasonal variation of the transport of black carbon aerosol from the Asian continent to the Arctic during the ARCTAS aircraft campaign, J. Geophys. Res., 116, D05202, doi:10.1029/2010JD015067, 2011.

Matsui, H., Koike, M., Kondo, Y., Oshima, N., Moteki, N., Kanaya, Y., Takami, A., and Irwin, M.: Seasonal variations of Asian black carbon outflow to the Pacific: Contribution from anthropogenic sources in China and biomass burning sources in Siberia and Southeast Asia, J. Geophys.Res., 118, 9947-9967, doi:10.1002/jgrd.50702, 2013.

Miyakawa, T., Oshima, N., Taketani, F., Komazaki, Y., Yoshino, A., Takami, A., Kondo, Y., and Kanaya, Y.: Alteration of the microphysical properties of black carbon through transport in the boundary layer in East Asia, Atmos. Chem. Phys. Discuss., doi:10.5194/acp-2016-570, in review, 2016.

Miyazaki, Y., Kondo, Y., Sahu, L. K., Imaru, J., Fukushima, N., and Kano, M.: Performance of a newly designed Continuous Soot Monitoring System (COSMOS), J. Env. Monit., 10, 1195-1201, doi:10.1039/b806957c, 2008.

Mori, T., Kondo, Y., Ohata, S., Moteki, N., Matui, H., Oshima, N., and Iwasaki, A.: Wet deposition of black carbon at a remote site in the East China Sea, J. Geophys. Res., 119, 10485-10498, doi:10.1002/2014JD022103, 2014.

Ohara, T., Akimoto, H., Kurokawa, J., Horii, N., Yamaji, K., Yan, $\mathrm{X}$., and Hayasaka, T.: An Asian emission inventory of anthropogenic emission sources for the period 1980-2020, Atmos. Chem. Phys., 7, 4419-4444, doi:10.5194/acp-7-4419-2007, 2007.

Oshima, N., Kondo, Y., Moteki, N., Takegawa, N., Koike, M., Kita, K., Matsui, H., Kajino, M., Nakamura, H., Jung, J. S., and Kim, Y. J.: Wet removal of black carbon in Asian outflow: Aerosol Radiative Forcing in East Asia (A-FORCE) aircraft campaign, J. Geophys. Res., 117, D03204,doi:10.1029/2011JD016552, 2012.
Pan, X. L., Kanaya, Y., Wang, Z. F., Liu, Y., Pochanart, P., Akimoto, H., Sun, Y. L., Dong, H. B., Li, J., Irie, H., and Takigawa, M.: Correlation of black carbon aerosol and carbon monoxide in the high-altitude environment of Mt. Huang in Eastern China, Atmos. Chem. Phys., 11, 9735-9747, doi:10.5194/acp-11-97352011, 2011.

Pan, X. L., Kanaya, Y., Wang, Z. F., Taketani, F., Tanimoto, H., Irie, H., Takashima, H., and Inomata, S.: Emission ratio of carbonaceous aerosols observed near crop residual burning sources in a rural area of the Yangtze River Delta Region, China, J. Geophys. Res., 117, D22304, doi:10.1029/2012JD018357, 2012.

Pan, X., Kanaya, Y., Wang, Z., Komazaki, Y., Taketani, F., Akimoto, H., Pochanart, P.: Variation of carbonaceous aerosols from open crop residue burning with transport and its implication to estimate their lifetimes, Atmos. Environ., 74, 301-310, 2013.

Park, S. S., Bae, M. S., Schauer, J. J., Ryu, S. S., Kim, Y. J., Cho, S. Y., and Kim S. J.: Evaluation of the TMO and TOT methods for $\mathrm{OC}$ and $\mathrm{EC}$ measurement and their characteristics in $\mathrm{PM}_{2.5}$ at an urban site of Korea during ACE Asia, Atmos. Environ., 39, 5101-5112, doi:10.1016/j.atmosenv.2005.05.016, 2005.

Petzold, A., Kramer, H., and Schönlinner, M.: Continuous measurement of atmospheric black carbon using a multi-angle absorption photometer, Environ. Sci. Poll. Res., 4, 78-82, 2002.

Sahu, L. K., Kondo, Y., Miyazaki, Y., Kuwata, M., Koike, M., Takegawa, N., Tanimoto, H., Matsueda, H., Yoon, S. C., and Kim Y. J.: Anthropogenic aerosols observed in Asian continental outflow at Jeju Island, Korea, in spring 2005, J. Geophys. Res., 114, D03301, doi:10.1029/2008JD010306, 2009.

Sahu, L. K., Kondo, Y., Miyazaki, Y., Pongkiatkul, P., and Kim Oanh, N. T.: Seasonal and diurnal variations of black carbon and organic carbon aerosols in Bangkok, J. Geophys. Res., 116, D15302, doi:10.1029/2010JD015563, 2011.

Shindell, D. T., Levy II, H., Schwarzkopf, M. D., Horowitz, L. W., Lamarque, J.-F., and Faluvegi, G.: Multi-model Projections of Climate Change From Short-lived Emissions Due To Human Activities. J. Geophys. Res. 113, D11109, doi:10.1029/2007JD009152, 2008.

Shiraiwa M., Kondo Y., Moteki N., Takegawa N., Sahu L. K., Takami A., Hatakeyama S., Yonemura S., Blake D. R.: Radiative impact of mixing state of black carbon aerosol in Asian outflow, J. Geophys. Res. 113, D24210, doi:10.1029/2008JD010546, 2008.

Streets, D. G., Bond, T. C., Carmichael, G. R., Fernandes, S. D., Fu, Q., He, D., Klimont, Z., Nelson, S. M., Tsai, N. Y., Wang, M. Q., Woo, J.-H., and Yarber, K. F.: An inventory of gaseous and primary aerosol emissions in Asia in the year 2000, J. Geophys. Res., 108, 8809, doi:10.1029/2002JD003093, 2003.

Takami A., Miyoshi T., Shimono A., Hatakeyama S.: Chemical composition of fine aerosol measured by AMS at Fukue Island, Japan during APEX period, Atmos. Environ., 39 4913-4924, 2005.

Tohjima, Y., Kubo, M., Minejima, C., Mukai, H., Tanimoto, H., Ganshin, A., Maksyutov, S., Katsumata, K., Machida, T., and Kita, K.: Temporal changes in the emissions of $\mathrm{CH} 4$ and $\mathrm{CO}$ from China estimated from $\mathrm{CH}_{4} / \mathrm{CO}_{2}$ and $\mathrm{CO} / \mathrm{CO}_{2}$ correlations observed at Hateruma Island, Atmos. Chem. Phys., 14, 16631677, doi:10.5194/acp-14-1663-2014, 2014.

UNEP and WMO: Integrated Assessment of Black Carbon and Tropospheric Ozone, United Nations Environment Program and 
World Meteorological Organization, Nairobi, Kenya, 285 pp., ISBN-13: 92 -807-3141-6, 2011.

Verma, R. L., Kondo, Y., Oshima, N., Matsui, H., Kita, K., Sahu, L. K., Kato, S., Kajii, Y., Takami, A., and Miyakawa, T.: Seasonal variations of the transport of black carbon and carbon monoxide from the Asian continent to the western Pacific in the boundary layer, J. Geophys. Res., 116, D21307, doi:10.1029/2011JD015830, 2011.

Wang, Q., Jacob, D. J., Fisher, J. A., Mao, J., Leibensperger, E. M., Carouge, C. C., Le Sager, P., Kondo, Y., Jimenez, J. L., Cubison, M. J., and Doherty, S. J.: Sources of carbonaceous aerosols and deposited black carbon in the Arctic in winter-spring: implications for radiative forcing, Atmos. Chem. Phys., 11, 1245312473, doi:10.5194/acp-11-12453-2011, 2011.

Wang, Y., Wang, X., Kondo, Y., Kajino, M., Munger, J. W., and Hao, J.: Black carbon and its correlation with trace gases at a rural site in Beijing: Top-down constraints from ambient measurements on bottom-up emissions, J. Geophys. Res. Atmos., 116, D24304, doi:10.1029/2011JD016575, 2011.

Wang, P., Wang, H., Wang, Y. Q., Zhang, X. Y., Gong, S. L., Xue, M., Zhou, C. H., Liu, H. L., An, X. Q., Niu, T., and Cheng, Y. L.: Inverse modeling of black carbon emissions over China using ensemble data assimilation, Atmos. Chem. Phys., 16, 989-1002, doi:10.5194/acp-16-989-2016, 2016.
Yamaji, K., Li, J., Uno, I., Kanaya, Y., Irie, H., Takigawa, M., Komazaki, Y., Pochanart, P., Liu, Y., Tanimoto, H., Ohara, T., Yan, X., Wang, Z., and Akimoto, H.: Impact of open crop residual burning on air quality over Central Eastern China during the Mount Tai Experiment 2006 (MTX2006), Atmos. Chem. Phys., 10, 7353-7368, doi:10.5194/acp-10-7353-2010, 2010.

Yumimoto, K., Uno I., and Itahashi S.: Long-term inverse modeling of Chinese $\mathrm{CO}$ emission from satellite observations. Environ. Pollut., 195, 208-318, doi:10.1016/j.envpol.2014.07.026, 2014.

Zhang, Q., Streets, D. G., Carmichael, G. R., He, K. B., Huo, H., Kannari, A., Klimont, Z., Park, I. S., Reddy, S., Fu, J. S., Chen, D., Duan, L., Lei, Y., Wang, L. T., and Yao, Z. L.: Asian emissions in 2006 for the NASA INTEX-B mission, Atmos. Chem. Phys., 9, 5131-5153, doi:10.5194/acp-9-5131-2009, 2009.

Zhang, X. Y., Wang, Y. Q., Niu, T., Zhang, X. C., Gong, S. L., Zhang, Y. M., and Sun, J. Y.: Atmospheric aerosol compositions in China: spatial/temporal variability, chemical signature, regional haze distribution and comparisons with global aerosols, Atmos. Chem. Phys., 12, 779-799, doi:10.5194/acp12-779-2012, 2012.

Zhang, J., Liu, J., Tao, S., and Ban-Weiss, G. A.: Long-range transport of black carbon to the Pacific Ocean and its dependence on aging timescale, Atmos. Chem. Phys., 15, 11521-11535, doi:10.5194/acp-15-11521-2015, 2015. 